\title{
Development of Multimode Gas Fired Combined Cycle Chemical-Looping Combustion Based Power Plant Lay-Outs
}

Basavaraja Revappa Jayadevappa ( $\sim$ basavarajarj@rvce.edu.in )

RV College of Engineering https://orcid.org/0000-0002-4853-1551

\section{Research Article}

Keywords: chemical looping combustion, lay-out, gaseous fuels, energy balance, multimode, carbon capture.

Posted Date: August 19th, 2021

DOI: https://doi.org/10.21203/rs.3.rs-735652/v1

License: (c) (1) This work is licensed under a Creative Commons Attribution 4.0 International License.

Read Full License 


\title{
Development of Multimode Gas Fired Combined Cycle Chemical-Looping Combustion Based Power
} Plant Lay-Outs

\author{
Basavaraja Revappa Jayadevappa* \\ Department of Chemical Engineering \\ *RV College of Engineering, Bengalure-560059, INDIA
}

*Author for correspondence; email: basavarajarj@rvce.edu.in

Address of the corresponding author:

Dr. Basavaraja Revappa Jayadevappa

Associate Professor

Department of Chemical Engineering

RV College of Engineering, Bengaluru 560059, INDIA

Tel. +918067178437

Fax +918067178011

17

18

19

20

21

22

23

24

25

26

27

28

29

30

31

32

33

34

35

36

37 
39 Ethics approval and consent to participate: No human/animals data are being used for the research 40 work.

41 Consent for publication: Not applicable

42 Availability of data and materials: Not applicable.

43 Competing interests: The authors declare that they have no competing interests

44 Funding: This research work has not funded by government/private agencies or institutions.

45 Authors' contributions: Complete work involved in literature findings, heat/mass balances, power 46 cycle calculations, layout development was being done by the single author Basavaraja R J

47

48

49

50

51

52

53

54

55

56

57

58

59

60

61

62

63

64

65

66

67

68 
Abstract

73 Operation of power plants in carbon dioxide capture and non-capture modes and energy penalty or energy utilization in such operations are of great significance. This work reports on two gas fired pressurized chemicallooping combustion power plant lay-outs with two inbuilt modes of flue gas exit namely, with carbon dioxide capture mode and second mode is letting flue gas (consists carbon dioxide and water) without capturing carbon dioxide. In the non-CCS mode, higher thermal efficiencies of $54.06 \%$ and $52.63 \%$ efficiencies are obtained with natural gas and syngas. In carbon capture mode, a net thermal efficiency of $52.13 \%$ is obtained with natural gas and $48.78 \%$ with syngas. The operating pressure of air reactor is taken to be 13 bar for realistic operational considerations and that of fuel reactor is 11.5 bar. Two power plant lay-outs developed based combined cycle CLC mode for natural gas and syngas fuels. A single lay-out is developed for two fuels with possible retrofit for dual fuel operation. The CLC Power plants can be operated with two modes of flue gas exit options and these operational options makes them higher thermal efficient power plants. 
104 NOTATION

105 CLC

Chemical-looping combustion

106 CC

Combined cycle

107 HRSG

Heat recovery steam generator

108 IGCC

Integrated gasification combined cycle

109 SMOC

Steam moderated oxyfuel combustion

$110 \mathrm{~h}_{\text {Air in }}$

Enthalpy in air entering into air reactor, $\mathrm{kJ} / \mathrm{kg}$

$111 \mathrm{~h}_{\text {Dep Air }}$

Enthalpy of oxygen depleted air reactor leaving the system, $\mathrm{kJ} / \mathrm{kg}$

$112 \mathrm{~h}_{\mathrm{MeO}}$

Enthalpy in oxygenated carrier, $\mathrm{kJ} / \mathrm{kg}$

$113 \mathrm{~h}_{\mathrm{Me}_{\mathrm{x}-1}}$

Enthalpy in enthalpy in reduced oxygen carrier, $\mathrm{kJ} / \mathrm{kg}$

$114 \mathrm{~h}_{\text {Fuel in }}$

Enthalpy flow in fuel entering fuel reactor, $\mathrm{kJ} / \mathrm{kg}$

$115 \mathrm{~h}_{\text {Exhaust }}$

Enthalpy flow in exhaust leaving fuel reactor, $\mathrm{kJ} / \mathrm{kg}$

$116 \Delta \mathrm{H}_{\mathrm{Ox}}$

Heat of oxidation, $\mathrm{kJ} / \mathrm{mol}$

$117 \Delta \mathrm{H}_{\text {Red }}$

$118 \mathrm{M}_{\text {Exhaust }}$

Heat of reduction, $\mathrm{kJ} / \mathrm{mol}$

$119 \quad \mathrm{M}_{\mathrm{O}_{2} \text { in }}$

Mass flow of exhaust (containing $\mathrm{CO}_{2}$ and water vapor) leaving fuel reactor per unit time, $\mathrm{kg} / \mathrm{s}$

$120 \quad \mathrm{M}_{\text {Dep Air }}$

Mass of oxygen in fresh air, entering to air reactor, $\mathrm{kg} / \mathrm{s}$

$121 \quad \mathrm{M}_{\mathrm{O}_{2} \text { out }}$

Mass of depleted air at the exit of air reactor, $\mathrm{kg} / \mathrm{s}$

$122 \mathrm{M}_{\text {Fuel in }}$

Mass of oxygen present in depleated air at the exit of the air reactor, $\mathrm{kg} / \mathrm{s}$

$123 \quad \mathrm{M}_{\text {Exhaust }}$

Mass of fuel entering into fuel reactor, $\mathrm{kg} / \mathrm{s}$

$124 \mathrm{M}_{\mathrm{MeO}_{\mathrm{x}}}$

Mass of exhaust gas (containing $\mathrm{CO}_{2}$ and water vapor) leaving fuel reactor respectively, $\mathrm{kg} / \mathrm{s}$

$125 \quad \mathrm{M}_{\mathrm{MeO}_{\mathrm{x}-1}}$

Mass of oxidized oxygen carrier, $\mathrm{kg} / \mathrm{s}$

$126 \mathrm{P}_{1}$

Mass of reduced oxygen carrier, $\mathrm{kg} / \mathrm{s}$

$127 \quad \mathrm{P}_{2}$

Compressor inlet pressure, bar

$128 \quad \mathrm{r}_{\mathrm{p}}$

Compressor outlet pressure, bar

$129 \mathrm{~T}$

Compression pressure ratio

$130 \mathrm{~T}_{1}$

Temperature at any point, ${ }^{\circ} \mathrm{C}$

$131 \mathrm{~T}_{2 \mathrm{~s}}$

Temperature of the gas at compressor inlet, $\mathrm{K}$

$132 \mathrm{~T}_{3}$

Isentropic temperature of gas at compressor exit, $\mathrm{K}$

$133 \mathrm{~T}_{4 \mathrm{~s}}$

Temperature of the fluid at gas turbine inlet and, $\mathrm{K}$

Isentropic temperature at gas turbine exit respectively, $\mathrm{K}$

$134 \gamma$

Specific heat capacity ratio

135

136

137

138

139 
141 Emission of greenhouse gas primarily carbon dioxide from power stations is a major concern for energy sectors,

142 climate change and terrestrial ecosystem (IPCC, 2014; IPCC, 2020). At present, carbon dioxide emission from

143 power sectors alone is $35-40 \%$ of the total $\mathrm{CO}_{2}$ emission and in these sectors fossil fuels accounts for the

144 anthropogenic $\mathrm{CO}_{2}$ emissions. Carbon dioxide concentration was increased in last one decade with an average

145 growth of $2.4 \mathrm{ppm} / \mathrm{year}$ and the 2020 concentration of $\mathrm{CO}_{2}$ is $415 \mathrm{ppm}$ and $\mathrm{CO}_{2}$ emissions is about $60 \%$ higher

146 compared to last 160 years (IEA, 2016; IEA, 2021). The various options in reducing emission of carbon to the

147 atmosphere is focused by many advanced combustion technologies and major research and concern is on: (i)

148 increasing efficiency by reducing energy consumption; (ii) use of less carbon emissive fuel; (iii) storage of $\mathrm{CO}_{2}$

149 using biological absorption methods in forest and soils (IPCC,2005; IPCC, 2007). The most of combustion

150 technologies involve energy penalty in flue gas cleaning and subsequent carbon capture. This should be

151 minimized to implement CCS with least energy penalty. There are several advantages with gas fuels (for

152 example natural gas and syngas) over high carbon emissive solid fuels to make power generation less $\mathrm{CO}_{2}$ -

153 intensive. The dependency of coal based power generation will continue in countries like India, China and South

154 Africa for the next 40 years (Jayanti et al., 2012).

155

156 Emissions of carbon dioxide from the power plants and industries have been great interest in by means of 157 carbon captured and sequestration (CCS) (IPCC, 2014). Three principal way to capture $\mathrm{CO}_{2}$ from flue gas upon 158 combustion in power plants; these are post-combustion capture, pre-combustion capture and oxyfuel combustion

159 (Ghonieum and Needs, 2011). Comparative analysis of natural gas fired oxyfuel and CLC based power plant 160 lay-outs is made by Basavaraja and Jayanti (2015a) and net efficiency reported for oxyfuel based $\mathrm{CC}^{\mathrm{CO}_{2}}$ 161 recycle and combined cycle steam moderated oxyfuel combustion (CC SMOC) is respectively $30.93 \%$ and $46.57 \%$ and CLC atmospheric and CC CLC is respectively $43.11 \%$ and $51.94 \%$ after incorporating energy

163 penalty for $\mathrm{CO}_{2}$ compression to $110 \mathrm{bar}$. Though state of art has been illustrated in these technologies with technical maturity (Wall 2007), many of these involves energy penalty in $\mathrm{CO}_{2}$ capture. Energy penalty for coal

165 based, post capture and compression is $12 \%$, oxyfuel combustion capture is $11.2 \%$, IGCC Shell is $9.4 \%$ and NGCC post combustion capture is $5.8 \%$ (Davison and Thambimuthu, 2009).

168 Existing power plants needs CCS with well-planned retrofitting. Development of present power plant with the 169 provision of CCS entails additional capital investment. Raymond et al. (2014) studied on retrofitting power 
170 plant for carbon sequestration and problems associated with carbon constrained energy planning (CCEP).

171 Operation of power plant with CCS involves number of factors like fuel type, electricity cost, and geographical

172 area for sequestration and environmental issues (Tola and Pettinau, 2014). A detailed analysis on fuel switching

173 for CLC based power plant layout was made by Basavaraja and Jayanti (2015b) to address alternative fuel as

174 energy source for atmospheric CLC plants by thermodynamic, transport and kinetic factors considerations. Oxy-

175 coal based combustion is gaining attention in research, Jayanti and Kareemulla (2016) studied on the low

176 temperature flashing for simultaneous $\mathrm{CO}_{2}$ and $\mathrm{SO}_{2}$ capture in oxy coal combustion based power plants. There

177 is a need for combustion technology that enables power plant is to be operated in both CCS and non-CCS mode.

178 Combustion in power plant based on CLC enables plant to operate with or without capture of $\mathrm{CO}_{2}$ with

179 minimum retrofit.

180

181 The concept of Chemical-looping combustion was proposed in 1954 to produce pure $\mathrm{CO}_{2}$ and later research work to increase thermal efficiency on reversibility of combustion processes using chemical-looping concept is

183 made (Lewis and Gilliand., 1954; Richter and Knoche., 1983; Ishida et al. , 1987 and Jin and Ishida., 1994).

184 The important parameters of CLC based plants, such as gas-solid contact pattern, oxygen carrier reactivity at

185 different temperatures for various fuels and temperature distribution in reactor system, are now well understood

186 by research (Adanez et al., 2012; Mansoor et al., 2017; Sumana et al. 2020, Jun and Xiang., 2021).

187 Technically mature Rankine-cycle type oxyfuel-combustion based power plants show 10 to $12 \%$ (Jayanti et al.,

188 2012; Jenni et al., 2013; Navajas et al., 2019) energy penalty even though thermal losses can be minimized by 189 proper design and optimization of power cycle. A studies on CLC based power plants show that energy loss

190 will be minimal (Naqvi, 2006; Kvamsdal, 2007; Navajas et al., 2019) in oxygen separation from air and such

191 studies made in integrated gasification combined cycle (IGCC) power plant with and without $\mathrm{CO}_{2}$ capture

192 (Petrescu and carmos, 2017). Pressurized CLC show higher thermal efficiency and there has been possibility of 193 operating in both CCS and non CCS modes. Jin and Ishida (2006), Abad et al.(2007) and Adanaz et al. (2006)

194 studied on kinetics of oxygen carriers in pressurized CLC environment in lab scale. These results cannot be used 195 to scale-up reactor but these show kinetics in 1 to 15 bar range CLC system will be feasible in case of heavy 196 duty CLC reactors. These studies shows operating CLC based units with high thermal efficiency without much 197 energy consumption for air separation with the feasibility of handling flue gas in CCS and non-CCS mode.

198 While studies on pressurized/combined cycle based CLC system operation (Naqvi 2006; Wolf 2004; Zang 
to handle flue gas with $\mathrm{CO}_{2}$ capture and free let-out have not properly addressed .

201 The objective of this work is to develop gas fired power plant lay-out incorporating two ways of handling flue

202 gas with a prospective to know heat generation sections and heat utilization to generate electrical power using

203 Brayton and Rankine cycles while still ensuring options of handling flue gas containing $\mathrm{CO}_{2}$ in $\mathrm{CCS}$ and non

204 CCS routes.

205 This paper aims to study, develop process flow sheet and analyse two gas fired pressurized chemical-looping combustion power plants and their configuration for two modes of operations i.e., one with carbon capture mode and other one is allowing flue gas from plant to atmosphere thereby enabling retrofitting possibility for fuel switch.

Three power plants based on pressurized chemical-looping combustion are considered and are :

(a) a natural gas fueled plant with and without carbon capture modes, (b) a syngas fueled plant with and without carbon capture modes, and (c) a future ready plant operating with and without carbon capture

\section{DEPICTION OF MASS AND ENERGY CALCULATION}

\subsection{Pressurized Chemical Looping Combustion}

216 The principle of pressurized chemical looping combustion is shown in Figure 1. Here, the fuel combustion is

217 split in two stages. Firstly, a solid metal (in a low oxidation state, denoted as MeOx-1) is oxidised by oxygen in

218 the air to form metal oxide (completely oxidized state, denoted as $\mathrm{MeOx}$ ) in air reactor. In the later stage, the 219 metal oxide gives oxygen to react with the hydrocarbon fuel during fluidization to form carbon dioxide and water vapor in fuel reactor. Two stage combustion of fuel by reactor systems eliminates oxygen separation unit and avoids mixing of $\mathrm{N}_{2}$ with flue gas. The exit gases from CLC reactor system are taken through gas turbines followed by heat recovery steam generators to generate power and $\mathrm{CO}_{2}$ separated from the flue gas upon cooling sent for compression. Pressurised operation of CLC reactor systems enables combined power cycles operated under gas turbine as per 
226 (Kehlhofer, 1999; El-Wakil, 2010). In recent years, pressurized CLC is gaining importance from the researches

227 in the view of reactor configuration, solid-gas contact, reaction kinetics, fuel conversion (Abad et al., 2007; Xiao

228 et al., 2010; Xiao et al.,2012; Zheng et al., 2014). Studies made by Adanez et al. (2006) and Garcia-Labiano et

229 al.(2006) shows that reduction of $\mathrm{NiO}$ to $\mathrm{Ni}$ oxygen carrier conversion remains $100 \%$ for $\mathrm{CH}_{4}, \mathrm{H}_{2}, \mathrm{CO}^{2}$ and $\mathrm{O}_{2}$

230 and conversion is reduced at higher pressure. This decrease in the solid conversion is typically in the range of

231 16-30 bar ranges and therefore in the present work we have chosen 13 bar pressure as highest gas pressure (at

232 depleted air turbine) at Brayton cycle. In the pilot plant studies (Erlach et al., 2011) showed no attrition and no

233 agglomeration when that $\mathrm{Ni} / \mathrm{NiO}$ can be operated at $1300^{\circ} \mathrm{C}$ in $\mathrm{CLC}$ units. Temperature and pressure for air

234 turbine of the Brayton cycle are fixed at $1200^{\circ} \mathrm{C}$ and $13 \mathrm{bar}$, respectively.

236 The heat required for the endothermic metal oxide reduction (by fuel) is supplied from the oxidized metal 237 coming from air reactor. Reaction in two CLC reactors is by gas-solid contact during fluidization. Based on 238 reactive nature of oxygen carrier with air and fuel, air reactor operates in circulating fluized bed mode and fuel 239 reactor operates in bubbling fluidized bed mode. Due to varying type of fluidization in air and fuel reactors

240 results more pressure drop and to account for this pressure in the fuel reactor is assumed to be 11.5 bar (at $2411150^{\circ} \mathrm{C}$ ) with the solid conversion of $80 \%$. Similar condition (Naqvi, 2006; Adanez et al. 2006) used in

242 literature for pressurized CLC systems. We have chosen this operating pressure for realistic operation of CLC 243 reactor system. The gases expanded to one bar from gas (air and exhaust) turbine are further cooled by heat

244 recovery steam generators to run steam turbines of Rankine cycle and water preheaters to preheat feed water.

245 Cooled depleted air let to atmosphere. Exhaust gas containing water vapor is separated $\mathrm{CO}_{2}$ upon cooling in flue 246 gas conditioner and more than $95 \%$ pure $\mathrm{CO}_{2}$ is compressed to a pressure of 110 bar for sequestration. Two 247 possible way of handling flue gas from CLC plant unit is shown in Figure 2, one without capturing $\mathrm{CO}_{2}$ and 248 another one with power consumption carbon. The energy balance and combined cycle arrangement is discussed in section 2.2.

\subsection{Energy balance}

252 In this section mass and energy balance details for the combined cycle CLC system are given. The Nickel oxide

$253(\mathrm{NiO})$ supported on Nickel di-aluminium tetroxide $\left(\mathrm{NiAl}_{2} \mathrm{O}_{4}\right)$ in a 60:40 weight ratio is chosen as oxygen 254 carrier. The nickel oxide flow rate calculation is made by considering $25 \%$ excess oxygen supply to fuel in fuel 
reactor. The CLC-reactors are assumed to be adiabatic with isothermal and homogenous mixing of solids with gases. Air flow rate is calculation is considered in air reactor with an 220\% of an excess air. Considering major components of the natural gas and syngas fuels, and their reaction with $\mathrm{NiO}$ is given as per reactions (1), (2) and (3) respectively with excess oxygen (Adanez et al., 2012):

$\mathrm{H}_{2}+\mathrm{NiO} \rightarrow \mathrm{Ni}+\mathrm{H}_{2} \mathrm{O}$

$$
\Delta \mathrm{H}=-15 \mathrm{~kJ} / \mathrm{mol} \mathrm{H}_{2}
$$

262 Nickel is oxidized to nickel oxide in air reactor as per reaction (4) given below

$$
\Delta \mathrm{H}=-468 \mathrm{~kJ} / \mathrm{mol} \mathrm{O}_{2}
$$

In reactions (1) to (4), values of heat of reaction shown has been estimated from the values available in literature (Adanez et al., 2012; Linderholm et al., 2008) for the temperature range $1150^{\circ} \mathrm{C}$ to $1230^{\circ} \mathrm{C}$. Based on reactions (1) to (4) stoichiometric oxygen requirement for syngas is calculated and in similar way other components of natural gas is estimated. One can see here that syngas composition consist major portions of carbon monoxide, hydrogen and lessor part of methane. Reaction of $\mathrm{CO}$ and $\mathrm{H}_{2}$ with $\mathrm{NiO}$ is exothermic compared to lessor methane gas endothermic reaction with $\mathrm{NiO}$. This make overall syngas reaction with $\mathrm{NiO}$ as mildly exothermic.

In this system, power is generated primarily by Brayton cycle and bottoming Rankine cycle. The basis for all CLC calculations is amount of fuel converted in the reduction/fuel reactor. In combined cycle CLC, metal oxidation reaction is taken up by large mass of excess air. With given fuel flow, the amount of oxygen converted is found from reaction stoichiometry, and the heat balance for the air reactor can be solved. Air and fuel reactors heat balance (as per Figure 3) is formulated respectively according to Eqs. (5) and (6):

$M_{\text {Fuel in }} h_{\text {Fuel in }}+M_{\text {MeO }_{x}} h_{M e O}-M_{\text {Fuel in }} \Delta H_{\text {Red }}=M_{\text {Exhaust }} h_{\text {Exhaust }}+M_{M_{e O}-1} h_{M_{x-1}}$

281 In Eq. (5), terms $\mathrm{h}_{\mathrm{MeO}}, \mathrm{h}_{\mathrm{Me}_{\mathrm{x}-1}}, \mathrm{~h}_{\text {Air in }}, \mathrm{h}_{\text {Dep Air }}$ are, respectively, the enthalpy in oxidized metal, reduced metal , air entering and oxygen depleted air leaving the air reactor. In Eq. (6), terms $\mathrm{h}_{\text {Fuel in }}$ and $\mathrm{h}_{\text {Exhaust }}$ are respectively, the enthalpy of fuel entering into fuel reactor and enthalpy of exhaust (stream containing $\mathrm{CO}_{2}$ and 
water vapor). $\Delta \mathrm{H}_{\mathrm{Ox}}$ is the heat of oxidation in $\mathrm{kJ} / \mathrm{mol}$ i.e,, heat released during reaction of $\mathrm{Ni}$ with $\mathrm{O}_{2}$ to form $\mathrm{NiO}$. The term $\Delta \mathrm{H}_{\text {Red }}$ is heat of reduction in $\mathrm{kJ} / \mathrm{mol}$ i.e., heat absorbed during the natural gas oxidation or $\mathrm{NiO}$ reduction. Ni oxidation is exothermic reaction and therfore the term $\Delta \mathrm{H}_{\mathrm{Ox}}$ associated with molar mass is with plus sign as given in Eq. (5) and $\mathrm{NiO}$ reduction in fuel reactor is endothermic for the natural gas fired case and thus the term $\Delta \mathrm{H}_{\text {Red }}$ associated with molar mass is with minus sign as given in Eq. (6) and same will be become plus sign for exothermic $\mathrm{NiO}$ reaction with syngas. Here $\mathrm{M}_{\mathrm{O}_{2} \text { in }}, \mathrm{M}_{\mathrm{Dep} \text { Air }}, \mathrm{M}_{\mathrm{O}_{2} \text { out }}, \mathrm{M}_{\mathrm{Fuel} \mathrm{in}}, \mathrm{M}_{\text {Exhaust }}$ are respectively mass of oxygen in the fresh air, mass of the depleted air, unreacted or excess oxygen leaving air reactor, mass of fuel entering into fuel reactor and mass of exhaust gas (containing $\mathrm{CO}_{2}$ and water vapor) leaving fuel reactor respectively. In Eqs.(5) and (6), $\mathrm{M}_{\mathrm{MeO}_{\mathrm{x}}}$ and $\mathrm{M}_{\mathrm{MeO}_{\mathrm{x}-1}}$ denotes oxidized and reduced states of oxygen carrier respectively.

\subsection{Pressurized chemical-looping combustion power cycle}

A schematic diagram of the pressurized CLC power cycle is shown in Figure 4. The CLC Brayton cycle consists of air compressor, depleted air turbine and exhaust gas $\left(\mathrm{CO}_{2}+\mathrm{H}_{2} \mathrm{O}\right)$ turbine. The fuel is assumed to be pressurized. The oxygen depleted air from the air reactor and exhaust stream containing $\mathrm{CO}_{2}$ and water vapor from the fuel reactor are drawn into two separate Brayton cycles and are expanded in an air turbine and $\mathrm{CO}_{2}$ turbine. The CLC reactor exit gases after expansion preheats the respective reactor inlet gases using gas-gas heat exchangers or recuperators. The heat left in the exhaust and depleted gas streams is extracted by using series of heat exchangers or heat recovery steam generators (HRSG) to generate steam as per Rankine cycle.

305 Figure 4 shows combined cycle chemical looping combustion power cycle arrangement having two Brayton cycles and a Rankine cycle.

\section{RESULTS AND DISCUSSION}

309 Thermal input for natural and syngas fired combined cycle CLC based power plant is considered as $761 \mathrm{MW}_{\mathrm{th}}$

310 and $800 \mathrm{MW}_{\text {th }}$ respectively, supplied in continuous fuel flow. The composition in mole \% of natural gas

311 (Linderholm et al. 2009) is taken as $89.51 \% \mathrm{CH}_{4}, 5.92 \% \mathrm{C}_{2} \mathrm{H}_{6}, 2.36 \% \mathrm{C}_{3} \mathrm{H}_{8}, 0.40 \%$ isobutene, $0.56 \%$ n-butane,

$3120.13 \%$ isopentane, $0.08 \%$ n-pentane, $0.06 \% \mathrm{C}_{6} \mathrm{H}_{12}, 0.28 \% \mathrm{~N}_{2}$ and $0.70 \mathrm{CO}_{2}$ with lower heating value of 49.17

$313 \mathrm{MJ} / \mathrm{kg}$. Syngas ( that generates almost two times the quantity of $\mathrm{CO}_{2}$ of that of natural gas upon complete 
314 combustion) molar composition (Winslow 1977) is taken to be $45.7 \% \mathrm{H}_{2}, 19.6 \% \mathrm{CO}, 6.6 \% \mathrm{CH}_{4}$ and $28.1 \%$

$315 \mathrm{CO}_{2}$ with the lower heating value of $11.2 \mathrm{MJ} / \mathrm{kg}$.

316 In both fuel fired case, comprehensive mass and energy balance is made and thermodynamic analysis is carried

317 on the gas preheaters, air reactor, the fuel reactor, gas turbines (depleted air and exhaust gas turbines) of Brayton

318 power cycle and steam turbines of Rankin power cycles. The results from these calculations are discussed 319 below.

\section{$320 \quad 3.1$ Lay-out of Natural Gas Fired Pressurised CLC}

321 In this section detailed mass and energy balance for power plant and complete process flow sheet of pressurized CLC plant is discussed and details of these are given below.

\subsubsection{Mass and Energy Balances}

324 Mass and heat balances are made on CLC reactor system conating five major CLC sub-units. These are the fuel 325 oxidation reactor (operating at $1150^{\circ} \mathrm{C}$ and 11.6 bar), the air oxidation reactor (operating at $1200^{\circ} \mathrm{C}$ and 13 bar), 326 the fuel and the air pre-heaters and coolant air flow. Mass flow of individual stream of these sub-units has been 327 found by balancing moles of reactant and product based on the fuel component mole fractions. Using Eqs. (5) 328 and (6) heat (energy) balances have been made for natural gas fueled combined cycle CLC system of $761 \mathrm{MW}_{\text {th }}$ fuel input. The resulting energy and mass flow rates in and out of these sub-units are shown in Figure 5.

331 Compressed air (at $177^{\circ} \mathrm{C}$ and 13.5 bar) at mass flow of $870.12 \mathrm{~kg} / \mathrm{s}$ is divides into two streams namely coolant 332 air flow of $58.44 \mathrm{~kg} / \mathrm{s}$ and the process air of $811.68 \mathrm{~kg} / \mathrm{s}$. Air of mass flow $811.68 \mathrm{~kg} / \mathrm{s}$ (with $215.55 \%$ excess

$333 \mathrm{O}_{2}$ ) is drawn to the CLC reactor system and heated air (at $420^{\circ} \mathrm{C}$ ) from recuperator enters air reactor where 59.7

$334 \mathrm{~kg} / \mathrm{s}$ of oxygen present in the air is selectively reacted with metal (containing of $218.95 \mathrm{~kg} / \mathrm{s} \mathrm{of} \mathrm{Ni,} 69.66 \mathrm{~kg} / \mathrm{s}$ of $335 \mathrm{NiO}$ and $232.21 \mathrm{~kg} / \mathrm{s}$ of $\mathrm{NiAl}_{2} \mathrm{O}_{4}$ ) to form metal oxide stream (containing of $348.31 \mathrm{~kg} / \mathrm{s} \mathrm{of} \mathrm{NiO}$ and $232.21 \mathrm{~kg} / \mathrm{s}$ 336 of $\mathrm{NiAl}_{2} \mathrm{O}_{4}$ ). Conversion of $\mathrm{NiO}$ to $\mathrm{Ni}$ is $80 \%$ in the fuel reactor. The Energy produced by exothermic metal 337 oxidation reaction in the air is taken out by $\mathrm{N}_{2}$ rich air (of flow $751.99 \mathrm{~kg} / \mathrm{s}$ ) and metal oxide streams. The heat 338 absorbed by endothermic metal oxide reduction reaction in fuel reactor is $113 \mathrm{MW}$. This is supplied by the 339 oxygen carrier. $15.47 \mathrm{~kg} / \mathrm{s}$ of natural gas is preheated from 30 to $350^{\circ} \mathrm{C}$ by the exhaust gas of $75.1 \mathrm{~kg} / \mathrm{s}$. The $\mathrm{O}_{2-}$ 340 depleted air from the air reactor is $751.99 \mathrm{~kg} / \mathrm{s}$ at $1200^{\circ} \mathrm{C}$. The oxygen depleted air and coolant air $(58.44 \mathrm{~kg} / \mathrm{s}$ at $341177^{\circ} \mathrm{C}$ ) mix at the turbine inlet to form a total mass flow of $810.43 \mathrm{~kg} / \mathrm{s}$ and a temperature of $1132^{\circ} \mathrm{C}$ at the 342 turbine inlet. The depleted air and coolant bleed mixture gases expand in the gas turbine. The depleted air 
turbine exit gas temperature at $1 \mathrm{bar}$ is $497^{\circ} \mathrm{C}$. Exhaust gas temperature reduces to $666^{\circ} \mathrm{C}$ upon expansion.

344 The computed value $\gamma\left(=C_{P} / C_{V}\right)$ for oxygen depleted air and fuel reactor exhaust given are 1.345 and 1.226,

345 respectively. These values are comparable with these reputed literatures (Naqvi et al., 2007; Wolf, 2004) for same inlet gas composition for depleted air and exhaust turbines. Depleted air at the exit of air reactor (at $1200^{\circ} \mathrm{C}$ ) mixes with the coolant air so that turbine inlet temperature is taken to be $1132^{\circ} \mathrm{C}$. Turbine efficiency $\left(\eta_{t}\right)$ is taken in the range of $91-92 \%$ (Wolf, 2004) and a value of $92 \%$ is used in the present studies. Nearly atmospheric pressure depleted air and exhaust gas streams (after expansion in gas turbines) at low pressure are used for power generation (as per Ranking Cycle) after preheating respective reactor inlet gases. The complete process description for the combined cycle chemical-looping combustion power plant flow diagram is given below (section 3.1.2).

353

\subsubsection{Natural gas Fired Power plant lay-out}

Chemical-looping combustion based combined cycle is unique compared to a conventional combined cycle as the depleted air from the air reactor and flue gas containing $\mathrm{CO}_{2}$ and water vapor from the fuel reactor are drawn into two separate Brayton cycles and are expanded in an air turbine and $\mathrm{CO}_{2}$ turbine. Combined cycle chemicallooping combustion power cycle consists of four major components namely compressor, recuperators, gas turbine and steam turbine.

Since combustion is divided into oxidation and reduction reactions in two pressurized fluidized bed reactors, therefore two gas turbines are used to expand them in the proposed lay-out. Gases are compressed to desired reactors operation using compressors. Recuperators provide necessary heat to preheat the reactants. Description of the streams in the process plant as shown in Figure 6 is described below.

The terms A1, A2, A3 denote fresh air streams and are respectively air before compression, air after first stage of compression and air at the exit of second compression stage. Major part of the compressed air (A4) is first preheated and then admitted to the air reactor to oxidise the reduced metal oxide (M2). The depleted air (A7) mixes with the cooling air (A5) drawn from air compressor and then expands down. The depleted air from the turbine exit (A8) preheats the fresh air (A4) to (A6). The depleted air from the turbine exit is further cooled from A9 to A10 by water stream (S8) to generate steam (S9). Pressurized fuel (F1) after preheating (F2) reacts with

372 the oxygenated metal carrier (M1) to form $\mathrm{CO}_{2}$ and $\mathrm{H}_{2} \mathrm{O}$ vapour mixture exhaust (E1). The expanded exhaust 

water stream S2 which form steam S3. The depleted air stream finally cools to $75^{\circ} \mathrm{C}$ (A10 to A11) while heating water stream (S5) to stream (S6). Thus, the exit gases from air turbine and exhaust gas are drawn into Rankine cycle through heat recovery steam generator to generate subcritical steam at $190^{\circ} \mathrm{C}(1.7 \mathrm{bar})$. The exhaust gas stream at $128^{\circ} \mathrm{C}$ is let to the atmosphere through chimney when power plant operates in without $\mathrm{CO}_{2}$ mode. To operate power plant in carbon capture mode as shown in Figure 7, the exhaust stream from fuel reactor is admitted to flue gas conditioner for further cooling to $\sim 40^{\circ} \mathrm{C}$ and the condensed water vapour is separated (E6) and $\mathrm{CO}_{2}$ gas (E7) is compressed to 110 bar (E8) at $35^{\circ} \mathrm{C}$. The isentropic efficiency of gas and steam turbines are assumed to be $92 \%$. Thermodynamic analysis of the natural gas fueled CC CLC is shown in the Table 1 . The efficiency of water pump and compressor are taken as $75 \%$ and $85 \%$ respectively.

\subsection{Lay-out of Syngas Fired Pressurised CLC}

Mass and Energy balance model is same as already presented in Section 3.1.1 for pressurized CLC with natural gas as the fuel has been used to determine the furnace side parameters for syngas firing. Since syngas has higher cost of compression of $\mathrm{CO}_{2}$, the lay-out has been designed for a $800 \mathrm{MW}_{\text {th }}$, which amounts to $71.43 \mathrm{~kg} / \mathrm{s}$ of syngas flow and is 4.6 higher than the flow rate of natural gas required for a $761 \mathrm{MW}_{\text {th }}$ plant. On the furnace side, the principal sub-systems considered are the air reactor and its preheater, the fuel reactor and its preheater, the gas turbines used to extract power from these exhausts and the compressor to supply air to the air reactors as well as coolant air to the air turbine. Syngas is assumed to be available under pressurized conditions and the cost of its compression is not included in the analysis. As in the case of syngas, the air reactor is fixed to operate at 13 bar and $1200^{\circ} \mathrm{C}$, and the fuel reactor is fixed to operate at the pressure of 11.6 bar (at $1226^{\circ} \mathrm{C}$ ). The same oxygen carrier is used and its flow rate has been determined for syngas requirements for an $800 \mathrm{MW}_{\text {th }}$ power plant. The operating temperature of the fuel reactor and the inlet and exit temperatures of the recuperators have been adjusted to account for the exothermicity of the reduction reaction in the syngas-fired fuel reactor. The specific heat capacity ratio $(\gamma)$ is taken as 1.20 . The resulting mass and energy flow rates into these subsystems are shown in Figure 8.

400 The process flow diagram for the CC CLC is shown in the Figure 9. Description of the streams in the process 401 plant is briefly explained below. The inlet and exit streams reactor system is same as natural gas layout. The 402 energy utilization from exit gas of the syngas fired power plant is given below. The expanded exhaust (E2) from 
404 heat to water stream S2 to form high pressure steam S3 which is superheated to S4 by the cooling exhaust gas

405 (E5 to E6). After expansion in the high pressure turbine (S5), the exit steam is reheated (S6) and fed to the medium pressure (20 bar) steam turbine. After expansion to 1.7 bar in the medium pressure turbine, it is mixed with steam generated in various sections (S3, S6 and S16) of process the plant from $\mathrm{O}_{2}$-depleted air and exhaust gas steams via heat recovery steam generators to produce superheated steam at 1.7 bar at a temperature $190^{\circ} \mathrm{C}$. It then finally expands from $190^{\circ}$ to $39^{\circ} \mathrm{C}$ (at 0.069 bar). The exhaust gas (E6) at temperature $128^{\circ} \mathrm{C}$ leaves the

410 plant through chimney to atmosphere. The thermodynamic properties of the streams at various locations is 411 shown in Thermodynamic analysis of the CC CLC is shown in the Table 2.

\section{3.3 Schematic Diagram of the non-CCS and CCS enabled modes Power Plant}

414 A schematic diagram of the proposed power cycle is shown in Figure 4. It is based on pressurized chemical 415 looping combustion of gaseous hydrocarbon fuels such as natural gas, syngas, biogas and shale gas. The combustion of the hydrocarbon fuels occurs in two stages in two separate reactors. In the fuel reactor, the fuel combusts with a metal oxide, e.g., $\mathrm{NiO}$ supported on $\mathrm{NiAl}_{2} \mathrm{O}_{4}$ in a 60:40 weight ratio (taken in present work) prepared in the form of micron-sized particles, and gets converted to $\mathrm{CO}_{2}$ and $\mathrm{H}_{2} \mathrm{O}$. In the process, the metal oxide gets reduced. It is therefore fed to the air reactor where it gets regenerated by reacting directly with air. Both the metal oxidation and the metal reduction reactions are carried in the range of 1150 to $1250^{\circ} \mathrm{C}$, depending on the reaction and on the fuel. A circulating fluidized bed type of configuration is envisaged for the cyclic oxidation/ reduction reactions of the metal/metal oxide. It is also proposed that the reactions are carried out at a pressure of 13 bar in the air reactor and at a slightly reduced pressure of 12 bar in the fuel reactor. The high temperature reactions in the reactors thus give rise to high temperature gaseous products at a pressure of 12 to 13 bar. These are expanded in separate air or gas turbines to near atmospheric pressure. The expanded gases will still be hot having a temperature of 500 to $700^{\circ} \mathrm{C}$ depending on the reactor and the fuel. These are then used partly to preheat the gaseous reactants and partly to generate a Rankine cycle to generate further electrical power. In the process of giving up heat for the Rankine cycle, the oxygen-depleted air from the air reactor gets cooled down to $\sim 120^{\circ} \mathrm{C}$ and is fed to a chimney as it contains little $\mathrm{CO}_{2}$. The exhaust from the fuel reactor too

430 gets cooled down to $\sim 100^{\circ} \mathrm{C}$ as it passes through the heat recovery systems. For the CCS mode of operation of 431 the power plant the exhaust stream (E6) is admitted into the flue gas conditioner where it is finally cooled to $40^{\circ} \mathrm{C}$ (E5). The condensed water vapour is separated (E6) and $\mathrm{CO}_{2}$ gas (E7) is compressed to 110 bar (E8) at 

implemented as shown in Figure 10.

- the use of a combined cycle operation to ensures high power output

- The use of chemical looping combustion mode of burning of hydrocarbon fuel enables $\mathrm{CO}_{2}$ capture as a built-in feature.

- The in-built feature of $\mathrm{CO}_{2}$ capture enables the power plant to be ready for CCS when it becomes mandatory. At that stage, minor changes in the gas flow path, after it gets cooled to $\sim 100^{\circ} \mathrm{C}$, are required and a provision to compress $\mathrm{CO}_{2}$ to 110 bar must be made. Thus, the retrofitting to implement

These aspects are elaborated further below.

448 A process flow diagram of the proposed power plant lay-out is shown in Figure 9. Based on mass and energy balances discussed in sections 3.1 and 3.2, this has been developed for a $761 \mathrm{MW}_{\text {th }}$ plant when fired with natural gas and $800 \mathrm{MW}_{\text {th }}$ when fired with syngas. Major have now been identified and the flow paths of the various material streams, such as air, hydrocarbon fuel, steam and metal oxide, have been identified. Process flow sheeting calculations have been done for four different modes of operation, namely, with natural gas firing with and without CCS, and with syngas firing with and without CCS and the pressure, temperature and flow rate at several important locations in the flow paths have been calculated. These are summarized in Table 3. The fact that the same lay-out descriptors can be used for all four configurations highlights the multi-mode capability of 456 the plant design. The two specific features, namely, dual fuel flexibility and readiness for CCS, engender small changes in the process stream flow paths. These have been identified in Figure 9. Fuel switching from syngas to natural gas requires the fuel reactor exhaust stream to go directly from E3 to E5, thus bypassing the high pressure and the medium pressure turbines of the Rankine cycle system. There should be a corresponding

460 bypassing of the relevant heat recovery steam generators by the water on the steam side. Switching from a non-

461 CCS mode (which is the current practice) to CCS mode (which may be required in future) requires the fuel 

the air chimney.

465 Finally, the overall efficiency of the power plant under various modes of operation is summarized in Table 3.

466 Here, a listing is made of the various processes by which power is produced and those by which power is consumed for the four configurations.

468 Overall energy analysis is made for power plant lay-outs and net efficiency for each case is evaluated using Eq.

469 (7) considering the energy penalties for gas compression and water circulation.

$470 \quad \eta_{\text {Net }}=\frac{P_{\text {Net CC CLC }}}{m_{\text {fuel }} \cdot Q_{\text {LHV }}}$

In Eq. (7), $\eta_{\text {Net }}$ is net efficiency of power plant, $m_{\text {fuel }}$ is mass flow rate of fuel in $\mathrm{kg} / \mathrm{s}, Q_{\mathrm{LHV}}$ is lower heating value $(\mathrm{kJ} / \mathrm{kg})$ of the fuel and $\mathrm{P}_{\mathrm{Net} \text { CC CLC }}$ is net power available for combined cycle chemical looping combustion power plant and $\mathrm{P}_{\mathrm{Net} \text { CC CLC }}$ evaluated uing Eq. (8)

$\mathrm{P}_{\mathrm{Net} \text { CC CLC }}=\mathrm{P}_{\mathrm{CO}_{2}+\text { Air }+ \text { steam }}-\mathrm{P}_{\text {Air comp }}-\mathrm{P}_{\mathrm{CO}_{2} \text { comp }}-\mathrm{P}_{\text {water pump }}$

477 In Eq. (8), $\mathrm{P}_{\mathrm{CO}_{2}+\text { Air+steam }}$ is power produced $(\mathrm{kW})$ by $\mathrm{CO}_{2} /$ exhaust, air and steam turbines, $\mathrm{P}_{\text {Air comp }}$ and

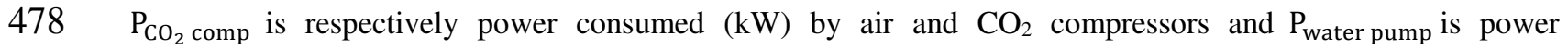
consumed $(\mathrm{kW})$ to pump water.

It can be seen that with CCS, a net thermal efficiency of $52.13 \%$ is obtained with natural gas and $48.78 \%$ with syngas using Eqs. (7-8). In the non-CCS mode (without $\mathrm{CO}_{2}$ compression), higher thermal efficiencies of 54.06 $\%$ and $52.63 \%$ efficiencies are obtained. The lower difference between the natural gas and the syngas in the non-CCS mode is reflective of the higher rate of $\mathrm{CO}_{2}$ generation in the latter per $\mathrm{MW}_{\text {th }}$ of the fuel. The high efficiencies obtained in all these cases are partly due to combined cycle operation, partly due to the use of supercritical boilers in the steam cycles and partly due to the use of chemical looping combustion as opposed to oxyfuel combustion. It may be noted that in these calculations, allowance has been made for non-idealities in the expansion, compression and pumping processes involving fluid flow. Allowance has also been made for the power required to compress $\mathrm{CO}_{2}$ to a pressure of 110 bar so that the nearly pure (purity > 99\%) can be sent to a 
492 Thus, it can be concluded the above power plant, which offers operational flexibility coupled with high

493 efficiency, has the necessary attributes of a future-ready power plant producing power from conventional

494 hydrocarbon fuels in an environmentally friendly way.

\subsection{Assessment of Possibility of Dual Fuel Operation}

In order to assess the possibility of dual fuel operation of the pressurized CLC system, a detailed comparison of several parameters associated with the two systems is made Table 4. It can be seen that most of the parameters are fairly similar; the operating temperature of the fuel reactors are slightly different. Due to the exothermicity of the reduction reaction, the fuel reactor temperature is actually higher than that of the air reactor by about $26^{\circ} \mathrm{C}$ with syngas, whereas it is lower by about $50^{\circ} \mathrm{C}$ in the case of natural gas firing. Another difference between the two fuels is the calorific value and the fuel gas flow rate. Since syngas contains significant amount of $\mathrm{CO}_{2}$ as inert, its flow rate is higher and the flow rate of the exhaust gas from the fuel reactor is also higher.

504 This, coupled with the higher exit temperature of the fuel reactor and lesser gas preheating requirement, results in significantly higher amount of thermal power (105.64 MW for syngas vs 51.71 MW for natural gas) retained in the fuel reactor exhaust gas (see Figure 5 and Figure 8) which is available for powering a Rankine cycle. As can be seen from Table 4, the Rankine cycle for syngas has three turbines (a high pressure turbine (150 bar), a medium pressure turbine (20 bar) and a low pressure turbine $(1.7 \mathrm{bar})$ ) while the one for natural gas has a single low pressure turbine with a turbine inlet pressure of 1.7 bar.

510 It can be seen that the major part of the power is produced by the low pressure turbine in the syngas case and

511 that its rating is roughly the same $\left(33,216 \mathrm{~kW}_{\mathrm{e}}\right.$ to $\left.29,396 \mathrm{~kW}_{\mathrm{e}}\right)$ as that of the low pressure turbine in the natural

512 gas case. The air reactor side parameters are nearly similar and there is hardly $5 \%$ change in the heat and mass

513 flow rates of various streams. From the above reasoning, it can be argued that except for minor changes in the

514 lay-out for the Rankine cycle parameters, the lay-outs of the syngas-fired and the natural gas-fired pressurized

515 CLC power plants are similar and a unified lay-out is produced in Figure 10. In this common lay-out, natural

516 gas firing requires by-passing of the fuel reactor exhaust from E3 to E6 directly. Correspondingly, the steam side too bypasses the high pressure and the medium pressure turbines and uses only the low pressure turbine.

518 The stream values corresponding to the unified lay-out are given in Table 1 for natural gas and Table 2 for syngas firing. These represent only minor departures from the normal settings and can be re-engineered without significant difficulty. This means that the thermodynamic compatibility between syngas and natural gas layouts for pressurized CLC can be achieved without significant retrofitting. The reaction engineering and 
transport phenomena considerations are similar to those already as our earlier work (Basavaraja and Jayanti,

523 2015b). While the kinetics of pressurized oxidation/ reduction reactors have not been fully worked out, it

524 appears that the kinetics of all the reactions are slowed down in a similar way in the pressure ranges considered

525 (Adanez et al., 2012; Garcia-Labiano et al. 2006). As demonstrated in our earlier work (Basavaraja and Jayanti,

526 2015b), the fluidization and heat transfer compatibility conditions can be met by careful design of the relevant

527 equipment. Thus, it appears that dual fuel flexibility can be incorporated into pressured CLC lay-out at the

528 design stage itself. In the Table 4, work reported by Naqvi and his co-workers (2007) for 697,545 kW thermal

529 in put natural gas fired pressurised CLC plant operates at $1200^{\circ} \mathrm{C}(13$ bar $)$ at air reactor and $980^{\circ} \mathrm{C}(11.6 \mathrm{bar})$ at

530 fuel reactor. The oxygen carriers, operating pressure (at air and $\mathrm{CO}_{2}$ turbines), compressor efficiency chosen is

531 same as reported by Naqvi and his co-workers (2007) for the natural gas fired CC CLC plant layout calculations

532 of the present work with $761,000 \mathrm{~kW}$ thermal input and the net efficiency is found to be $52.13 \%$ and which is

533 comparable net efficiency reported by Naqvi and his co-workers (2007). The detailed analyses of CC CLC

534 reactor operating conditions, power produced at gas and steam turbines, power consumed for air and $\mathrm{CO}_{2}$ compression, net efficiencies are shown in Table 4.

536

\section{FUTURE-READINESS OF THE LAY-OUT}

539 The lifetime of a thermal power plant is in excess of 50 years. While carbon capture and sequestration is not

540 mandatory right now, it is possible that it may become so in a decade or two. In this scenario, it is necessary to

541 build power plants that are future-ready, i.e., which can be made to operate in a case where CCS becomes

542 mandatory. Extensive retrofitting of the power plant to accommodate carbon capture may not be possible and

543 should be avoided. From the future-compatibility point of view, a chemical looping combustion-based power

544 plant is clearly the superior design. CLC plants can work in either CCS mode or non-CCS mode with very little

545 changes required to make the switch. No special efforts or equipment will be necessary to enable $\mathrm{CO} 2$ capture.

546 If CCS is not needed, then the flue gas from the flue gas conditioner need not be compressed and can be sent

547 directly to the chimney. When CCS is required, then this flue gas can be diverted to a CO2 compressor. In the

548 case of a power plant based on oxyfuel combustion, more extensive changes are required as an air separation

549 unit is required for generating pure oxygen. While studies (Jayanti et al. 2012) indicate that retrofitting of 550 atmospheric air combustion coal-fired boilers for working in oxyfuel mode, is possible, the case for pressurized 551 oxyfuel combustion may be different because flue gas compression and recirculation are necessary. In the case 
of pressurized oxyfuel combustion, the flow rates and composition of the exhaust gas are significantly different from those under air combustion; this may warrant changes in the turbine and heat recovery systems.

\section{CONCLUSION}

In the present study, analysis of two modes of operation of two gas fired pressurised chemical-looping combustion based power plant has been made. The principle conclusions drawn from the study is given:

- From the detailed mass and heat balances and thermodynamic analysis, power plant lay-outs have been prepared for pressurised CLC based power plant for fuels natural gas and syngas.

- Two modes of power plant operation, one not requiring CCS (the present day mode) and one requiring CCS (in a future scenario), have been considered within the ambit of pressurized CLC-based power plant. It is shown that since CLC generates $\mathrm{CO}_{2}$-rich flue gas (contains $\mathrm{CO}_{2}$ and water vapor only) which is ready for sequestration, the power plant can be readily operated in a dual mode with a loss of $2 \%$ of net thermal efficiency with natural gas and up to $4 \%$ for syngas.

- Oxyfuel combustion based power plants are technically mature in terms of proven commercial scale operation of new elements. They also have competitive net thermal efficiency if pressurised steam moderated oxyfuel combustion (SMOC)-based oxyfuel combustion is used. However, they make a poor choice in terms of future readiness of fuel/equipment flexibility and may warrant significant 
Abad A, Adánez J, García-Labiano F, Diego LFD, Gayán P, Celaya J. Mapping of the range of operational conditions for $\mathrm{Cu}-, \mathrm{Fe}_{-}$, and Ni-based oxygen carriers in chemical-looping combustion. Chem Eng Sci $591 \quad 2007 ; 62: 533-49$.

Abad A, Adánez J, García-Labiano F, Diego LFD, Gayán P, Celaya J. Mapping of the range of operational conditions for $\mathrm{Cu}-, \mathrm{Fe}-$, and Ni-based oxygen carriers in chemical-looping combustion. Chem Eng Sci 2007;62:533-49.

Adanez J, Abad A, Garcia-Labiano F, Gayan P. Diego LFD. Progress in chemical-looping combustion and reforming technologies. Prog Energy Combust Sci. 2012;38:215-82.

Adanez J, Garcia-Labiano F, DiegoLFD, Gayan P, Celaya J, Abad, A. Nickel-copper oxygen carriers to reach zero $\mathrm{CO}$ and $\mathrm{H}_{2}$ emissions in chemical-looping combustion. Ind Eng Chem Res 2006;45:2617-2625.

Adanez, J., Gayan, P., Celaya, J., de Diego, L. F., Garcia-Labiano F. and Abad, A. Chemical Looping combustion in a 10kWth prototype using a $\mathrm{CuO} / \mathrm{Al} 2 \mathrm{O} 3$ oxygen carrier: Effect of operating conditions on Methane combustion. Ind. Eng. Chem. Res. 2006; 45:6075-6080.

602 Basavaraj R. J., Jayanti S. Syngas-fueled, chemical-looping combustion-based power plant lay-out for clean 603 energy generation. Clean Technol and Environ Policy 2015c;17;237-247.

604 Basavaraja, R. J. and Jayanti, S. Comparative Analysis of four Gas-Fired, Carbon Capture-enabled Power Plant 605 Lay-outs. J. Clean Technol. and Environ 2015a:17:2143-2156.

606 Basavaraja, R. J. and Jayanti, S. Viability of Fuel Switching of a Gas-fired Power Plant Operating in Chemical607 Looping Combustion Mode. Energy 2015b:81: 213-221.

608 Brandvoll O, Bolland O. (2004). Inherent $\mathrm{CO}_{2}$ capture by using chemical looping combustion in a natural gas 609 fired power cycle. J. Eng. Gas Turbines Power, 126:316-321.

610 Davison J and Thambimuthu K. An overview of technologies and costs for carbon dioxide capture in power 611 plants. Proc I Mech E Part A: J Power Energy 2009; 223:201-212.

612 El-Wakil, Mohamed M. Power Plant Technology. 3rd ed. New Delhi: Tata McGraw Hill; 2010, India.

613 Erlach B, Schmidt M, Tsatsaronis G. Comparison of carbon capture IGCC with pre-combustion decarbonisation 614 and with chemical-looping combustion. Energy 2011; 36:3804-15.

615 G. Zang, J. Jia, S. Tejasvi, A. Ratner, E.S. Lora. Techno-economic comparative analysis of biomass integrated 616 gasification combined cycles with and without $\mathrm{CO}_{2}$ capture International Journal of Greenhouse Gas Control 617 2018, 78:73-84.

618 Garcia-Labiano F, Adanez J, Diego LFD, Gayan P, Abad A. Effect of Pressure on the Behavior of Copper- , 619 Iron-, and Nickel-Based Oxygen Carriers for Chemical-Looping Combustion Energy Fuels 2006;1:26-33.

620 Ghoniem, A. F. Needs, resources and climate change: clean and efficient conversion technologies. Progress in 621 Energy and Combustion Science 2011; 37: 15-51.

622 IEA (2016). IEA statistics: $\mathrm{CO}_{2}$ emissions from fuel combustion, International Energy Agency, Paris, France.

623 IEA (2021), Net Zero by 2050, IEA, Paris https://www.iea.org/reports/net-zero-by-2050.

624 IPCC (2007). Climate Change 2007: Synthesis Report. Contribution of working groups I, II and III to the 625 Fourth Assessment Report of the Intergovernmental Panel on Climate Change. IPCC, Geneva, Switzerland.

626 IPCC (2014). Climate Change 2014: Synthesis Report. Contribution of working groups I, II and III to the Fifth 627 Assessment Report of the Intergovernmental Panel on Climate Change. IPCC, Geneva, Switzerland.

628 IPCC (2019): Climate Change and Land: an IPCC special report on climate change, desertification, land 629 degradation, sustainable land management, food security, and greenhouse gas fluxes in terrestrial ecosystems. 630 IPCC, Geneva, Switzerland. In press. 
631 IPCC special report on carbon dioxide capture and storage. Cambridge, UK: Cambridge University Press; 2005.

632 Ishida M, Zheng D, Akehata T. Evaluation of a chemical-looping combustion power-generation system by 633 graphic exergy analysis. Energy 1987, 2: 147-154.

634 Ishida, M. and Jin H. A new advanced power-generation system using chemical-looping combustion. Energy $635199419: 415-422$.

$636 \mathrm{~J}$ Wolf, $\mathrm{CO}_{2}$ Mitigation in Advanced Power Cycles- Chemical Looping Combustion and Steam-Based 637 Gasification. Doctoral Thesis: Royal Institute of Technology; 2004.

638 Jayanti S and Kareemulla, D. Detailed plant layout studies of oxy-enriched $\mathrm{CO}_{2}$ pulverized coal combustion639 based power plant with $\mathrm{CO}_{2}$ enrichment. J. Clean Technol. and Environ 2016:18:1985-1996.

640 Jayanti S, Saravanan V, and Sivaji S. Assessment of retrofitting possibility of an Indian pulverized coal boiler 641 for operation with Indian coals in oxy-coal combustion mode with $\mathrm{CO}_{2}$ sequestration. Proc. I Mech E Part A: J

642 Power Energy 2012;226:1003-1013.

643 Jenni KE, Baker ED, Nemet JF. Expert elicitations of energy penalties for carbon capture technologies. Int J 644 Greenhouse Gas Control 2013;12: 136-45.

645 Jin H, Ishida M. Reactivity study on a novel hydrogen fueled chemical-looping combustion. Int J Hydrogen 646 Energy 2001;26: 889-894.

647 Jun Hu Shiyi and Chen Wenguo Xiang. Ni, Co and Cu-promoted iron-based oxygen carriers in methane-fueled 648 chemical looping hydrogen generation process. Fuel Process Techn, 2021; 221: 106917

649 Kehlhofer RH. Combined cycle gas and steam turbine power plants.2nd ed. Oklahoma: Penn Well; 1999.

650 Kvamsdal HM, Jordal K, Bolland O. A quantitative comparison of gas turbine cycles with $\mathrm{CO}_{2}$ capture. Energy $6512007 ; 32: 10-24$.

652 Letitia Petrescu, Calin-Cristian Cormos. Environmental assessment of IGCC power plants with pre653 combustion CO2 capture by chemical \& calcium looping methods. J. Clean. Production 2017; 158:233-244. 654 https://doi.org/10.1016/j.jclepro.2017.05.011

655 Lewis WK., and Gilliand ER (1954). Production of pure carbon dioxide. US Patent 2665972.

656 Linderholm C, Abad A, Lyngfelt A, Mattisson T. $160 \mathrm{~h}$ of chemical-looping combustion in a $10 \mathrm{~kW}$ reactor 657 system with a NiO-based oxygen carrier. Int J Greenh Gas Control 2008; 2:520-530.

658 Linderholm, C., Mattisson, T. and Lyngfelt, A. Long-term integrity testing of spray dried particles in a $10 \mathrm{~kW}$ 659 chemical-looping combustor using natural gas as fuel. Fuel 2009; 88: 2083-2096.

660 Mansour Mohammedramadan Tijani, Aqsha Aqsha, Nader Mahinpey. Synthesis and study of metal-based

661 oxygen carriers $(\mathrm{Cu}, \mathrm{Co}, \mathrm{Fe}, \mathrm{Ni})$ and their interaction with supported metal oxides $(\mathrm{Al} 2 \mathrm{O} 3, \mathrm{CeO} 2, \mathrm{TiO} 2, \mathrm{ZrO} 2)$

662 in a chemical looping combustion system, Energy 2017; 138:873-882.

663 Naqvi, R., Wolf, J. and Bolland, O. Part load analysis of a chemical looping combustion combined cycle for $664 \mathrm{CO}_{2}$ capture. Energy 2007; 32: 360-370.

665 Navajas et al. Life cycle assessment of natural gas fuelled power plants based on chemical looping combustion

666 technology. Energy Conversion and 2019:111856.

667 https://doi.org/10.1016/j.enconman.2019.111856

668 Ooi REH, Foo DCY and Tan RR. Targeting for carbon sequestration retrofit planning in the power generation 669 sector for multi-period problems. Applied Energy 2014;113:477-87.

670 Richter HJ, Knoche KF. Reversibility of combustion processes. ACS Symposium Series 1983; 71-85.

671 Shadab Alam J, Pradeeep Kumar K, Yamuna Rani, C Sumana. Comparative assessment of performances of 672 different oxygen carriers in a chemical looping combustion coupled intensified reforming process through 
675 Tola V, Pettinau A. Power generation plants with carbon capture and storage : A techno-economic comparison 676 between coal combustion and gasification technologies. Applied Energy 2014;113:1461-74.

677 Wall TF.Combustion processes for carbon capture. Proc. Combust. Inst. 2007; 31, 31-47.

678 Winslow. A. M. (1977). Numerical model of coal gasification in a packed bed. Symposium (international) on 679 combustion. 16, 503-513.

680 Xiao R, Chen LY, Saha C, Zhang S, Bhattacharya S. Pressurized chemical-looping combustion of coal using an 681 iron ore as oxygen carrier in a pilot-scale unit. Int J Greenh Gas control 2012;10:363-73.

682 Xiao R, Song QL, Zhang SA, Zheng WG, Yang YC. Pressurized chemical-looping combustion of Chinese 683 bituminous coal: cyclic performance and characterization of iron ore-based oxygen carrier. Energy Fuel $6842010 ; 24: 1449-63$.

685 Zheng, M., Shen, L. and Feng, X. In situ gasification chemical looping combustion of a coal using the binary 686 oxygen carrier natural anhydrite ore and natural iron ore. Energy Convers Manag 2014; 83:270-283.

687

688

689

690

691

692

693

694

695

696

697

698

699

700

701

702

703

704

705

706

707 
$710 \quad$ Figure 1: $\quad$ Schematic illustration of pressurized chemical-looping combustion

711

712
Figure 2: $\quad$ Schematic of flue gas handling in proposed chemical-looping combustion based power plant

Figure 3: $\quad$ Schematic of energy flow in combined cycle chemical-looping combustion

Figure 4: $\quad$ Arrangement of combined cycle CLC power cycle

Figure 5: $\quad$ Furnace side heat balance of $761 \mathrm{MW}_{\text {th }}$ natural gas fueled combined cycle chemical looping combustion plant

Figure 6: $\quad$ Schematic of natural gas fueled combined cycle chemical-looping combustion power plant without the provision for carbon capture

Figure 7: $\quad$ Schematic of natural gas fired $761 \mathrm{MW}_{\text {th }}$ combined cycle chemical-looping combustion power plant with provision of carbon capture

Figure 8: $\quad$ Furnace side heat balance for $800 \mathrm{MW}_{\text {th }}$ syngas fueled combined cycle CLC based power plant

Figure 9: $\quad$ Schematic of syngas fueled combined cycle chemical-looping combustion power plant without the provision for carbon capture

Figure 10: $\quad$ Schematic diagram of multi-fuel compatible combined cycle CLC based power plant lay-out with provisions for, with CCS and, without CCS modes

\section{LIST OF TABLES}

Table 1:

Detailed thermodynamic analysis of natural gas fueled $761 \mathrm{MW}_{\text {th }}$ combined cycle chemicallooping combustion power plant

Table 2: $\quad$ Detailed thermodynamic analysis of syngas fueled $800 \mathrm{MW}_{\text {th }}$ combined cycle chemicallooping combustion

Table 3: $\quad$ Energy analysis of combined cycle CLC based power plants operating in CCS and non CCS modes

Table 4: $\quad$ Overall energy analysis for combined cycle CLC 


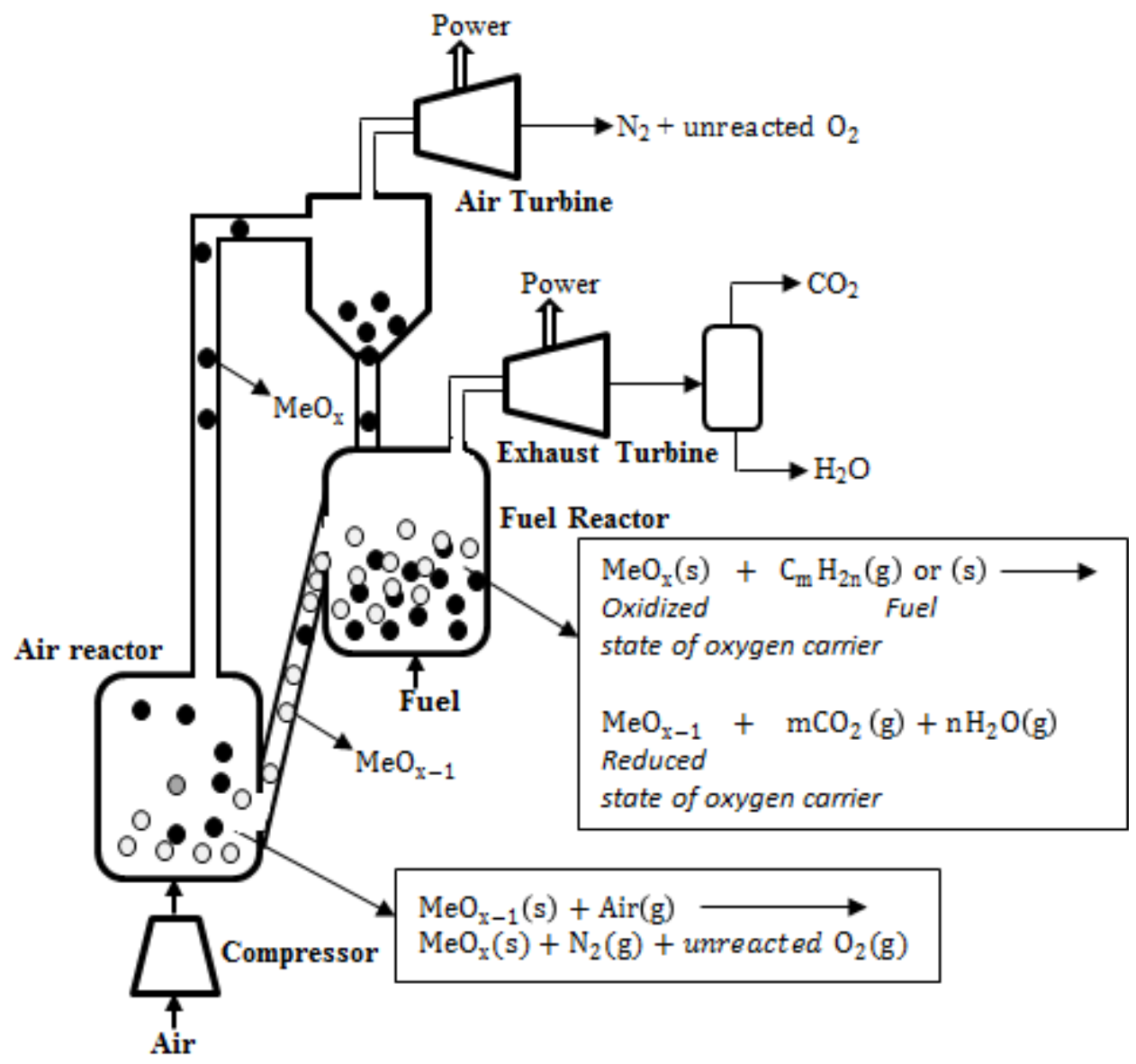

Figure 1: Schematic illustration of pressurized chemical-looping combustion 


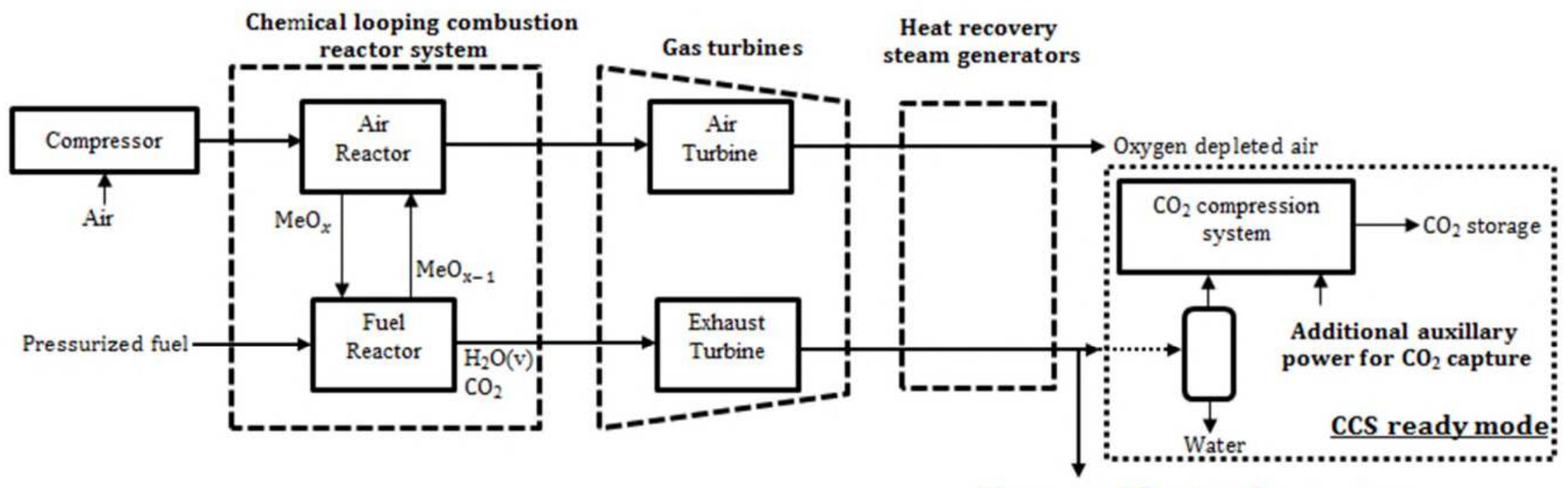

Flue gas without carbon capture 


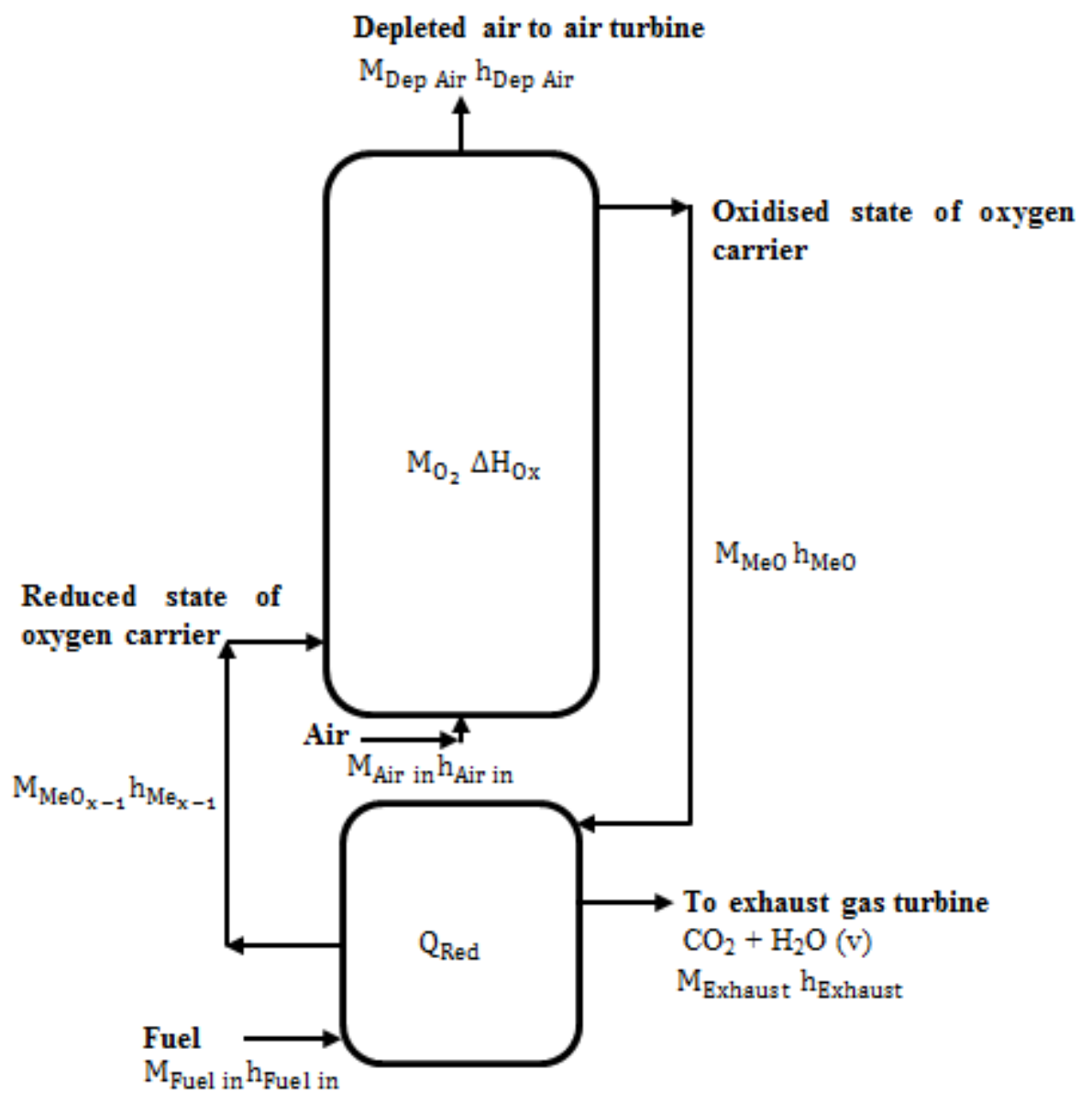

Figure 3: Schematic of energy flow in combined cycle chemical-looping combustion

778

779

780

781

782

783

784

785

786

787

788

789 


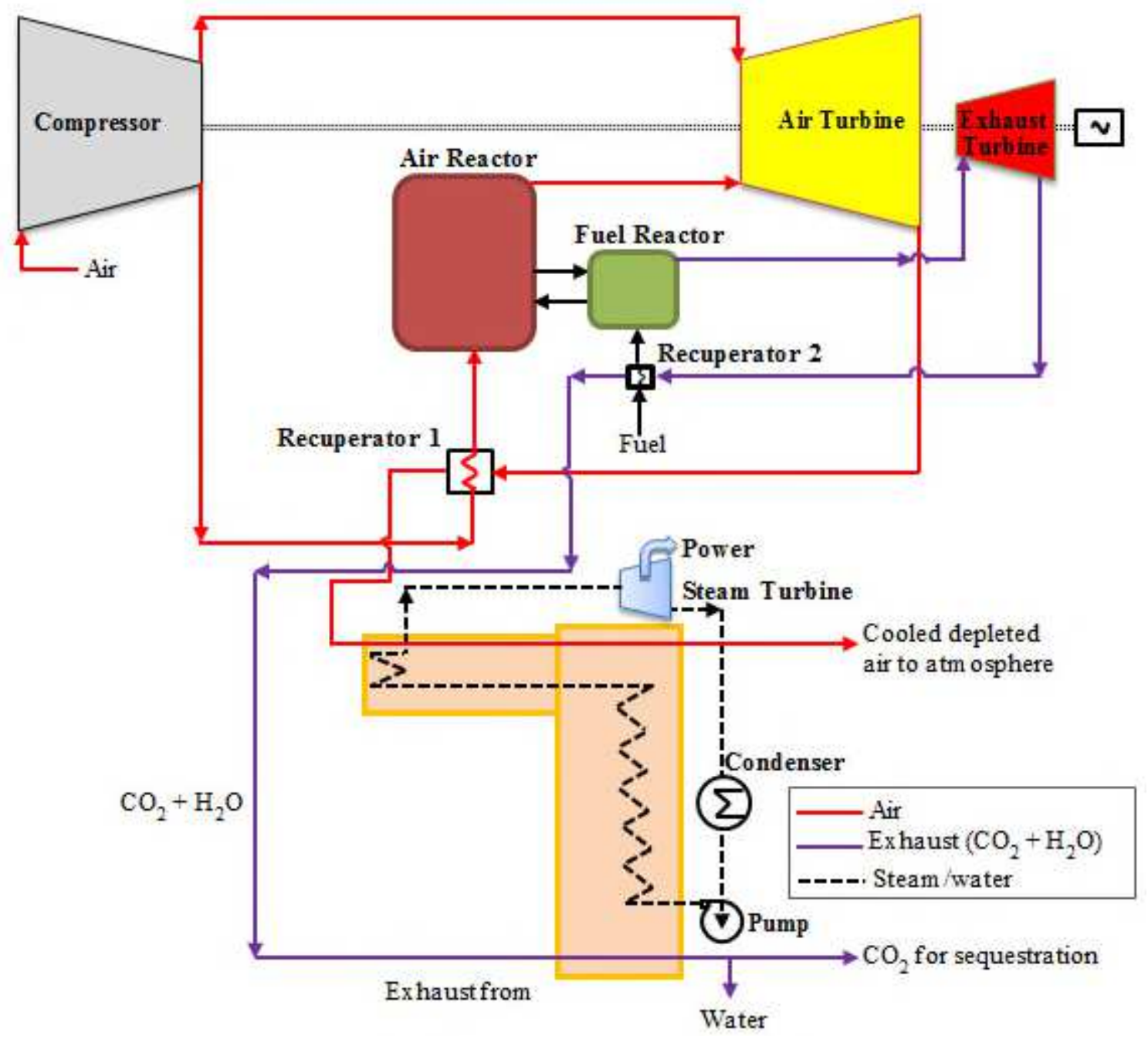




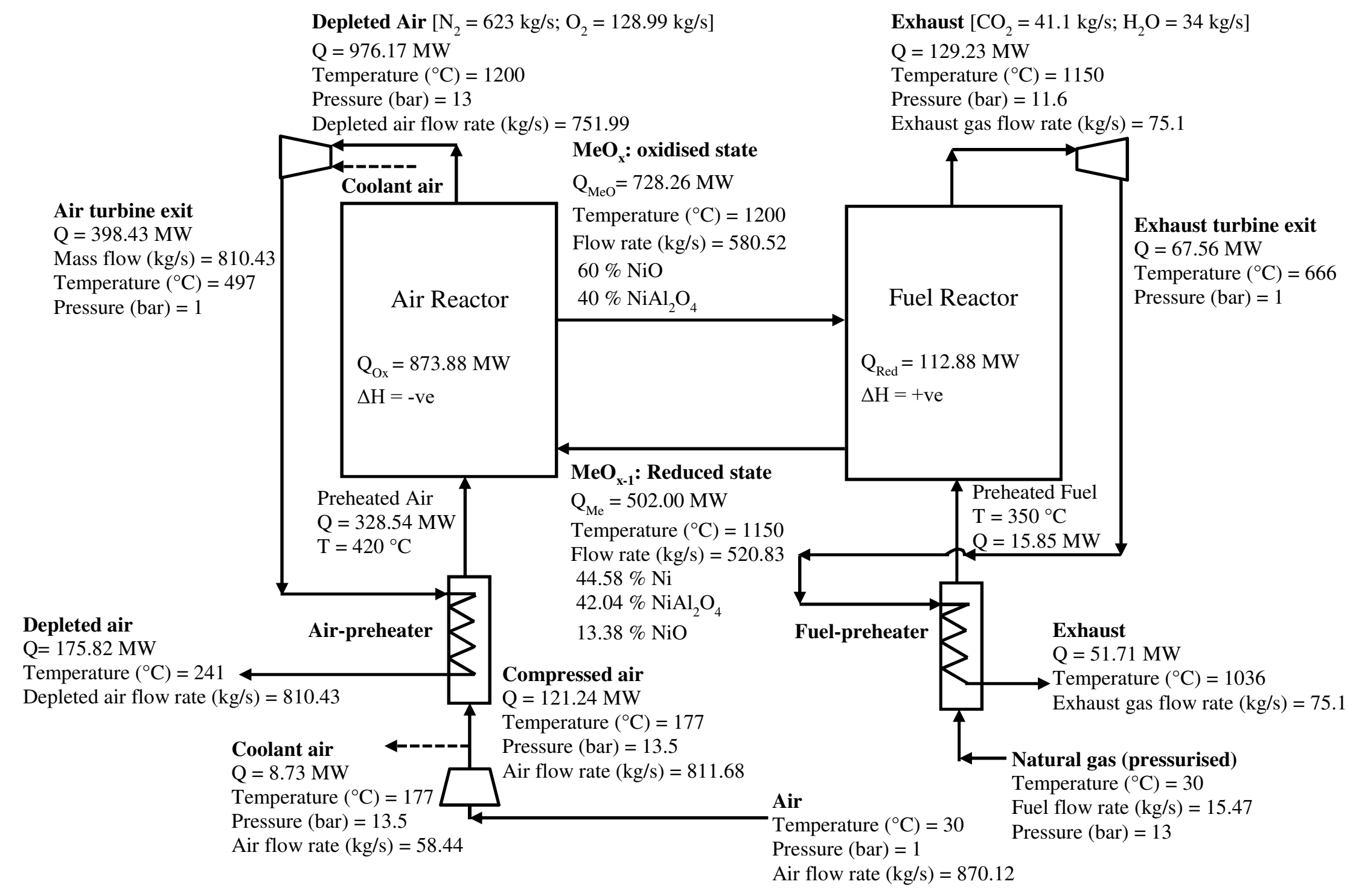

Figure 5 Furnace side heat balance of $761 \mathrm{MW}_{\text {th }}$ natural gas fueled combined cycle chemical looping combustion 


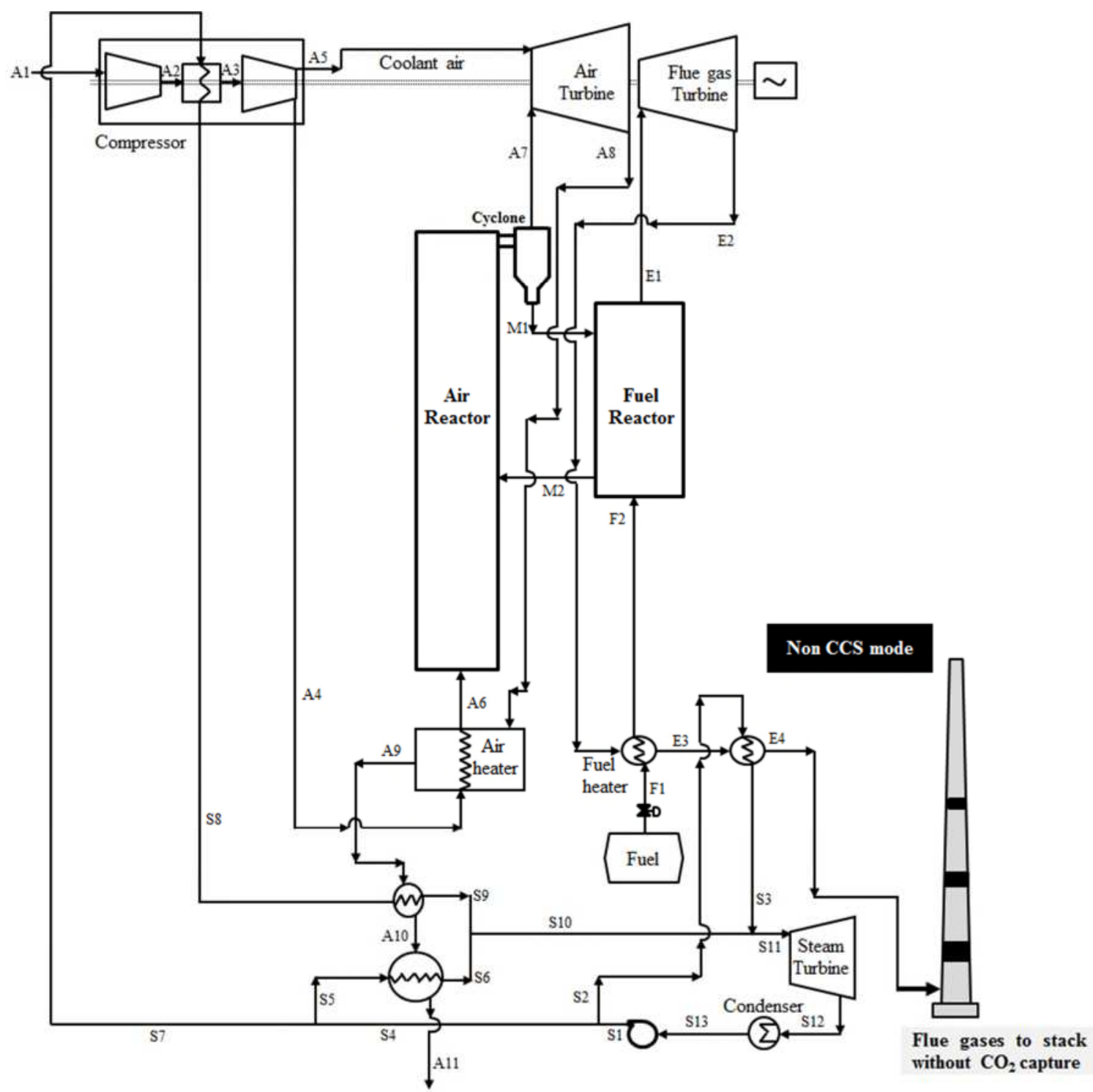

Figure 6: Schematic of natural gas fueled combined cycle chemical-looping combustion power plant without the provision for carbon capture 


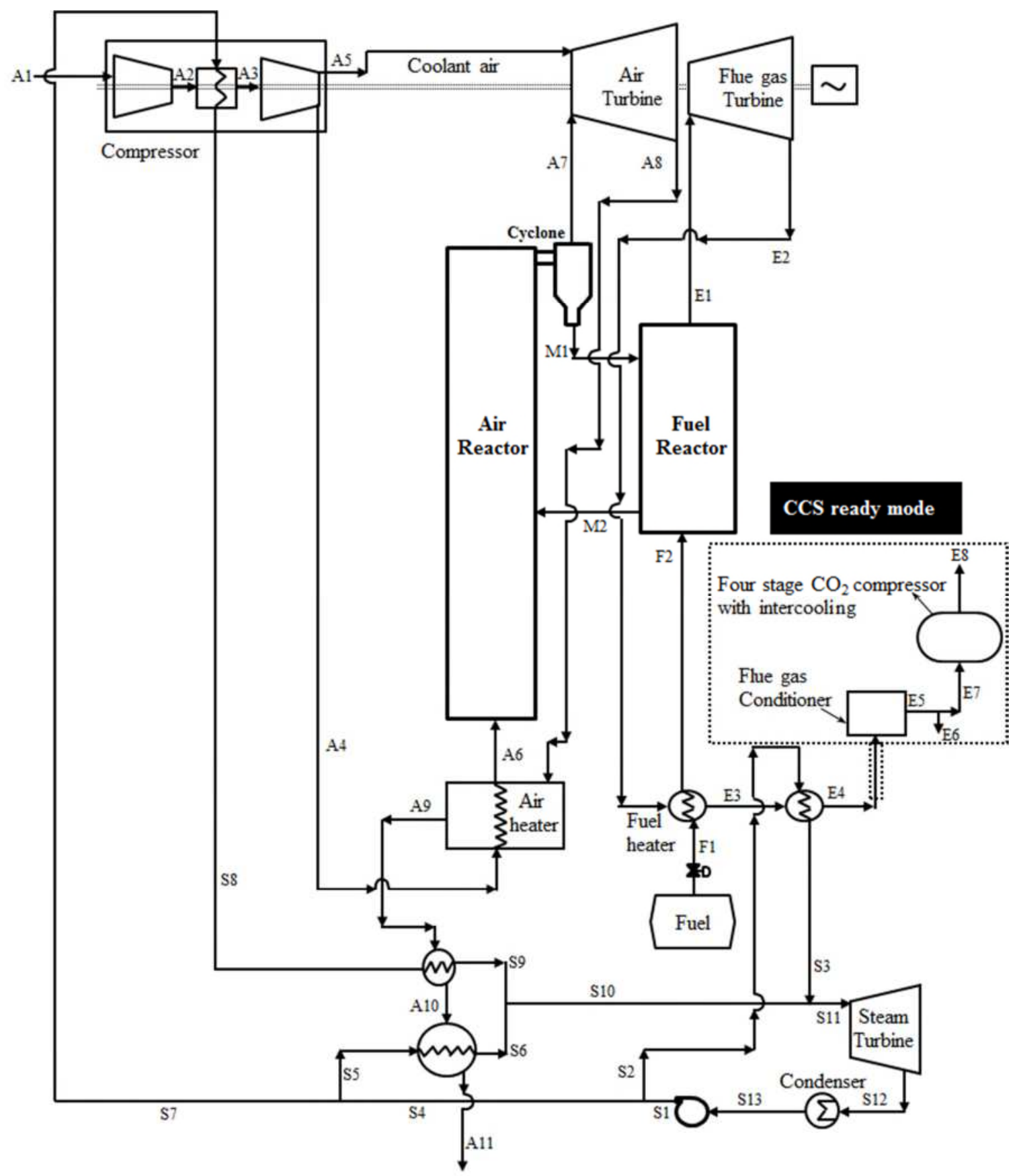

Figure 7: Schematic of natural gas fired $761 \mathrm{MW}_{\text {th }}$ combined cycle chemical-looping combustion power plant with provision of carbon capture 


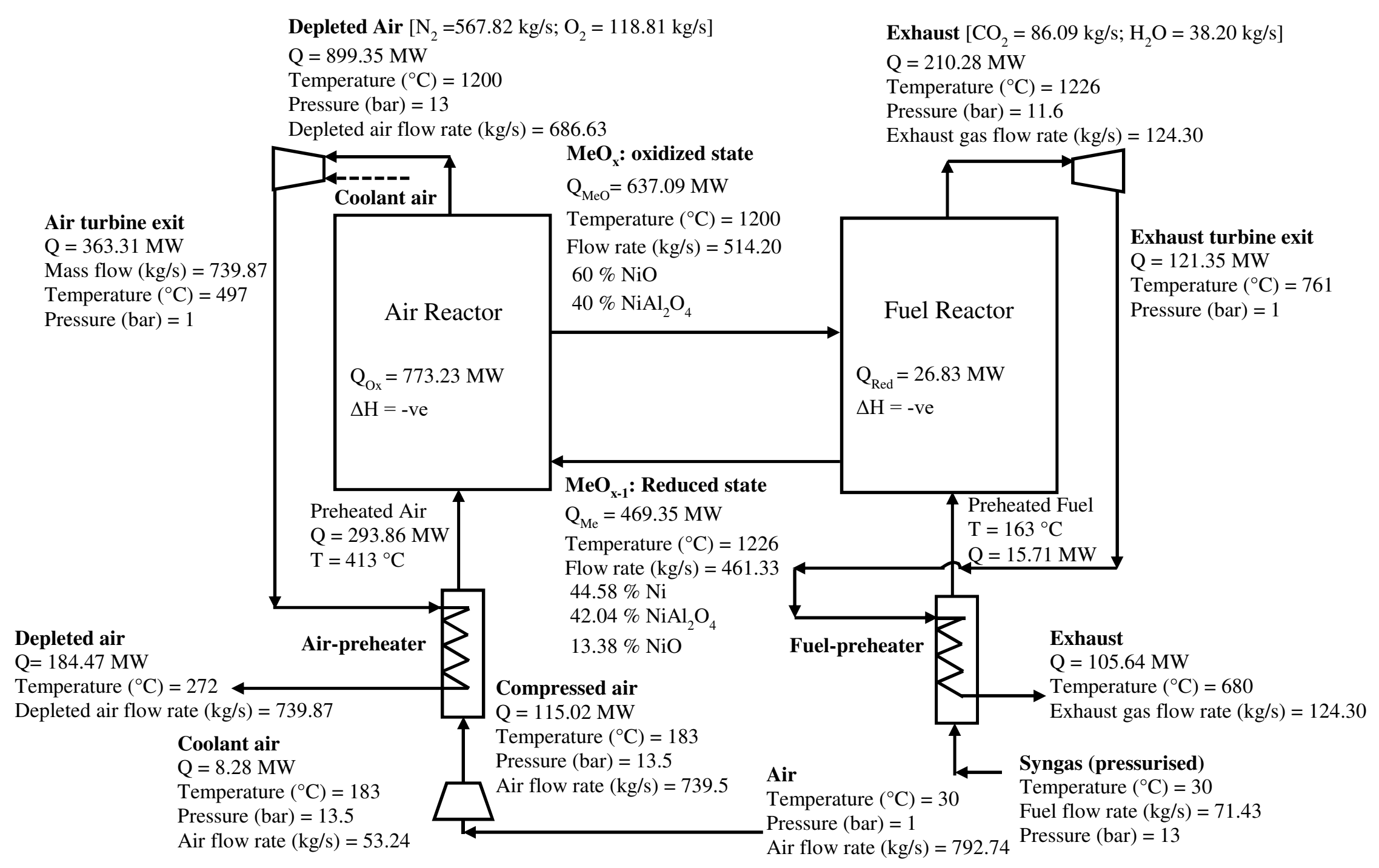

Figure 8: Furnace side heat balance for $800 \mathrm{MW}_{\text {th }}$ syngas fueled combined cycle CLC based power plant 


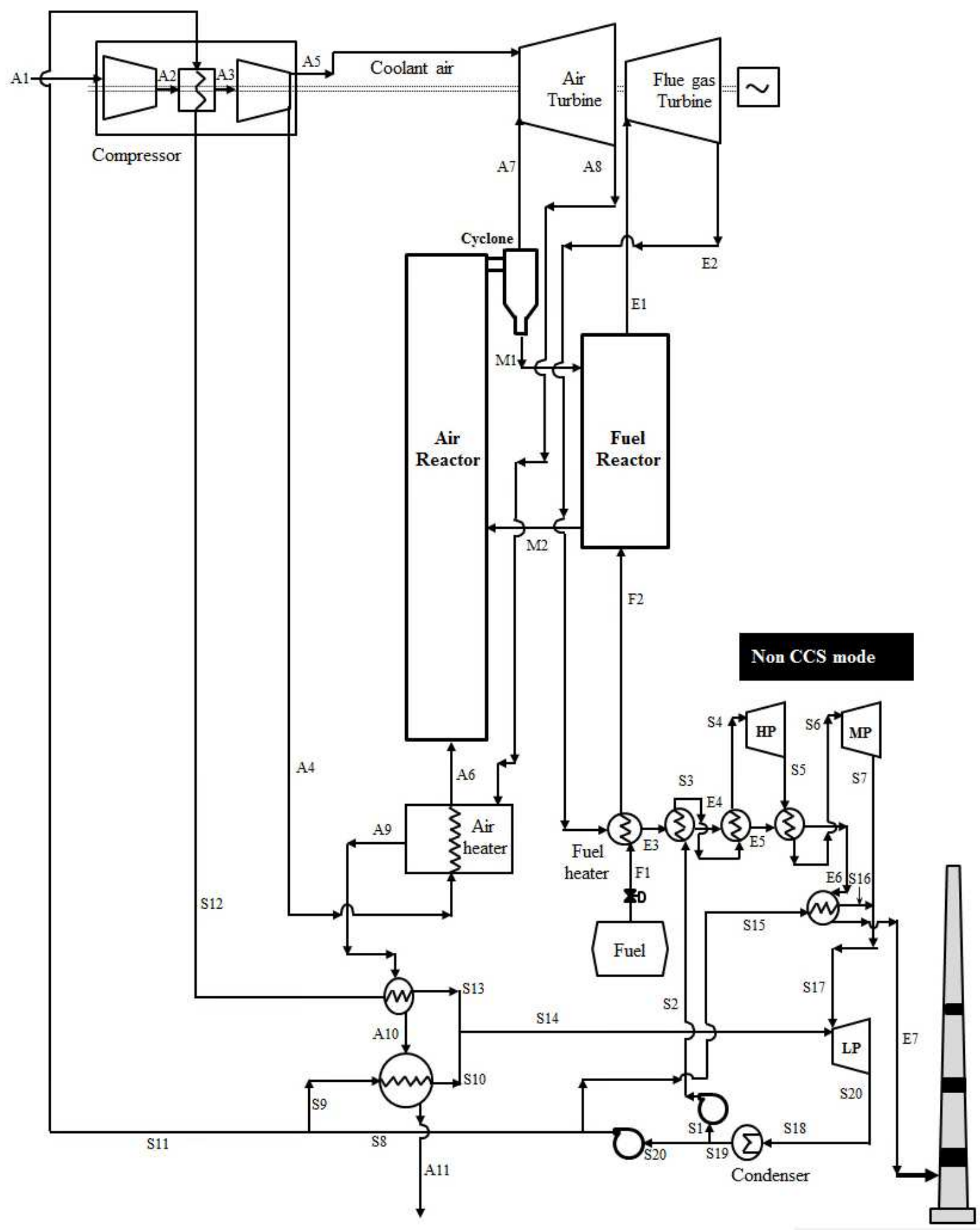

Flue gases to stack without $\mathrm{CO}_{2}$ capture

Figure 9: Schematic of syngas fueled combined cycle chemical-looping combustion power plant without the provision for carbon capture 


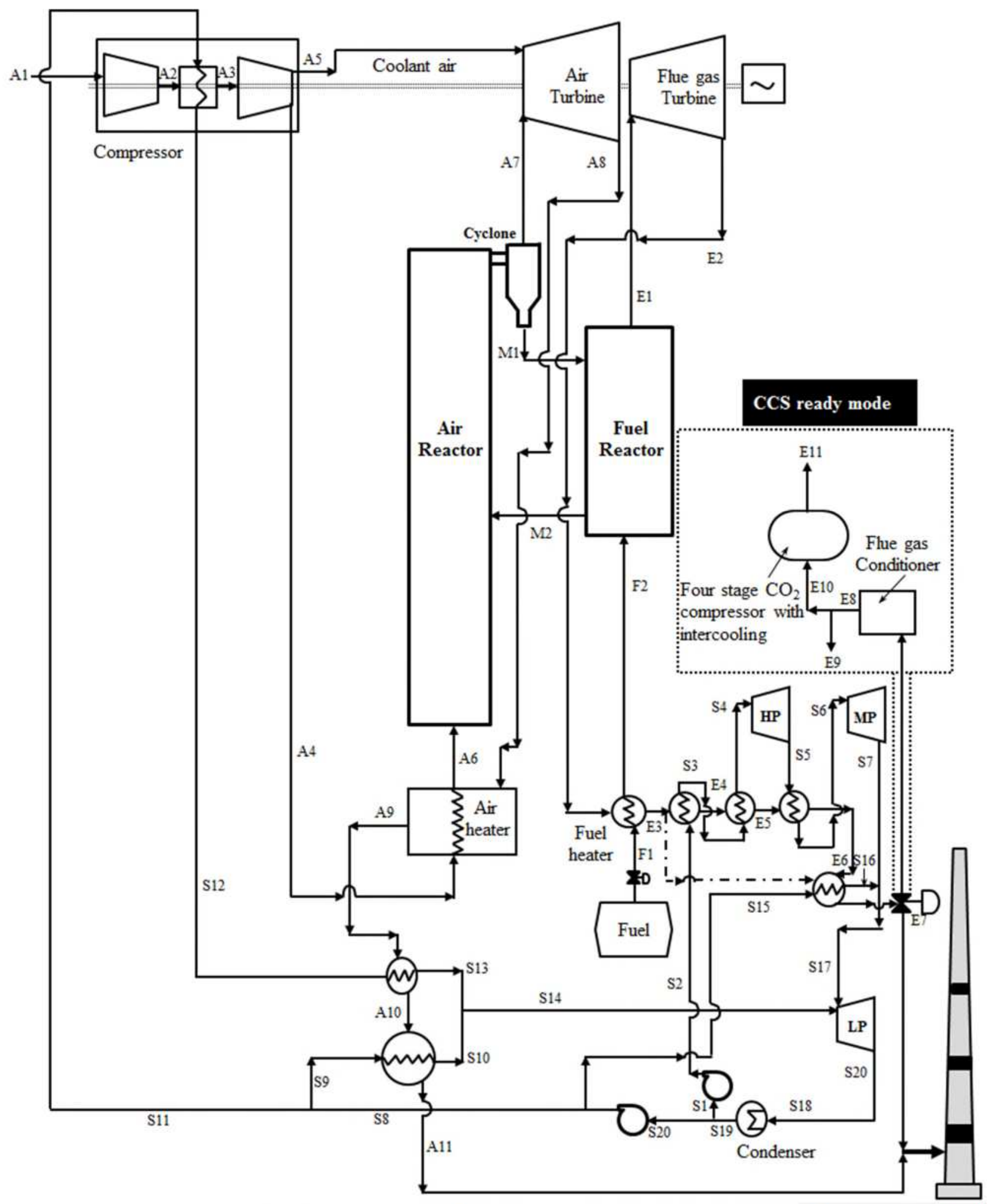

-.-Exhaust gas flow path to produce steam for LP turbine for natural gas fired case

Flue gases to stack without $\mathrm{CO}_{2}$ capture

Figure 10: Schematic diagram of multi-fuel compatible combined cycle CLC based power plant lay-out with provisions for, with CCS and, without CCS modes 
Table 1: Detailed thermodynamic analysis of natural gas fueled $761 \mathrm{MW}_{\text {th }}$ combined cycle chemicallooping combustion power plant

\begin{tabular}{|c|c|c|c|c|c|}
\hline Stream & $\mathrm{T}\left({ }^{\circ} \mathrm{C}\right)$ & $\mathrm{T}(\mathrm{K})$ & $\mathrm{P}$ (bar) & $\mathrm{m}(\mathrm{kg} / \mathrm{s})$ & $\mathrm{h}(\mathrm{kJ} / \mathrm{kg})$ \\
\hline \multicolumn{6}{|l|}{ Air } \\
\hline A1 & 30 & 303.15 & 1.01 & 870.12 & 0.00 \\
\hline $\mathrm{A} 2$ & 152 & 425.15 & 3.43 & 870.12 & 123.71 \\
\hline $\mathrm{A} 3$ & 35 & 308.15 & 13.50 & 870.12 & 5.02 \\
\hline A4 & 177 & 450.15 & 13.50 & 811.68 & 149.37 \\
\hline A5 & 177 & 450.15 & 13.50 & 58.44 & 149.37 \\
\hline A6 & 420 & 693.15 & 13.50 & 811.68 & 404.77 \\
\hline A7 & 1200 & 1473.15 & 13.00 & 751.99 & 1298.12 \\
\hline A8 & 497 & 770.15 & 1.01 & 810.43 & 491.62 \\
\hline A9 & 241 & 514.15 & 1.01 & 810.43 & 216.94 \\
\hline A10 & 234 & 507.15 & 1.01 & 810.43 & 209.92 \\
\hline A11 & 74 & 347.15 & 1.01 & 810.43 & 44.34 \\
\hline \multicolumn{6}{|l|}{ Fuel } \\
\hline $\mathrm{F} 1$ & 30 & 303.15 & 13.00 & 15.47 & 0.00 \\
\hline $\mathrm{F} 2$ & 350 & 623.15 & 13.00 & 15.47 & 1607.00 \\
\hline \multicolumn{6}{|l|}{ Exhaust } \\
\hline E1 & 1150 & 1423.15 & 11.60 & 75.1 & 1720.79 \\
\hline E2 & 1036 & 1309.15 & 1.01 & 75.1 & 211.06 \\
\hline E3 & 463 & 736.15 & 1.01 & 75.1 & 568.26 \\
\hline E4 & 128 & 401.15 & 1.01 & 75.1 & 72.03 \\
\hline E5 & 40 & 313.15 & 1.01 & 75.1 & 23.56 \\
\hline E6 & 40 & 313.15 & 1.05 & 34 & 41.72 \\
\hline E7 & 40 & 313.15 & 1.05 & 41.1 & 8.54 \\
\hline E8 & 35 & 308.15 & 110.00 & 41.1 & 4.26 \\
\hline \multicolumn{6}{|c|}{ Oxygen carrier } \\
\hline M1 & 1200 & 1473.15 & 13.00 & 580.52 & 1254.49 \\
\hline M2 & 1150 & 1423.15 & 11.60 & 520.83 & 963.85 \\
\hline \multicolumn{6}{|c|}{ Steam/water } \\
\hline S1 & 31 & 304.15 & 1.70 & 104.81 & 4.17 \\
\hline $\mathrm{S} 2$ & 31 & 304.15 & 1.70 & 18.13 & 4.17 \\
\hline $\mathrm{S} 3$ & 190 & 463.15 & 1.70 & 13.07 & 2852.17 \\
\hline $\mathrm{S} 4$ & 31 & 304.15 & 1.70 & 86.68 & 4.17 \\
\hline $\mathrm{S} 5$ & 31 & 304.15 & 1.70 & 46.95 & 4.17 \\
\hline S6 & 190 & 463.15 & 1.70 & 46.95 & 2852.17 \\
\hline S7 & 31 & 304.15 & 1.70 & 39.73 & 4.17 \\
\hline S8 & 120 & 393.15 & 1.70 & 39.73 & 2709.16 \\
\hline S9 & 190 & 463.15 & 1.70 & 39.73 & 2852.17 \\
\hline $\mathrm{S} 10$ & 190 & 463.15 & 1.70 & 86.68 & 2852.17 \\
\hline $\mathrm{S} 11$ & 190 & 463.15 & 1.70 & 104.81 & 2852.17 \\
\hline $\mathrm{S} 12$ & 39 & 312.15 & 0.07 & 104.81 & 2571.70 \\
\hline S13 & 30 & 303.15 & 1.01 & 104.81 & 0.00 \\
\hline
\end{tabular}


Table 2: Detailed thermodynamic analysis of syngas fueled $800 \mathrm{MW}_{\mathrm{th}}$ combined cycle chemical-looping combustion

\begin{tabular}{|c|c|c|c|c|c|c|c|c|c|c|c|}
\hline Stream & $\mathrm{T}\left({ }^{\circ} \mathrm{C}\right)$ & $\mathrm{T}(\mathrm{K})$ & P (bar) & $\mathrm{m}(\mathrm{kg} / \mathrm{s})$ & $\mathrm{h}(\mathrm{kJ} / \mathrm{kg})$ & Stream & $\mathrm{T}\left({ }^{\circ} \mathrm{C}\right)$ & $\mathrm{T}(\mathrm{K})$ & P (bar) & $\mathrm{m}(\mathrm{kg} / \mathrm{s})$ & $\mathrm{h}(\mathrm{kJ} / \mathrm{kg})$ \\
\hline Air & & & & & & Oxygen carrier & & & & & \\
\hline A1 & 30 & 303.15 & 1.01 & 792.74 & 0.00 & M1 & 1200 & 1473.15 & 13 & 514.20 & 1238.99 \\
\hline $\mathrm{A} 2$ & 152 & 425.15 & 3.43 & 792.74 & 123.71 & M2 & 1226 & 1499.15 & 11.6 & 461.33 & 1017.38 \\
\hline A3 & 35 & 308.15 & 13.5 & 792.74 & 5.02 & Steam/water & & & & & \\
\hline A4 & 183 & 456.15 & 13.5 & 739.50 & 155.54 & $\mathrm{~S} 1$ & 30 & 303.15 & 1.01 & 9.64 & 0.00 \\
\hline A5 & 183 & 456.15 & 13.5 & 53.24 & 155.54 & $\mathrm{~S} 2$ & 31 & 304.15 & 150 & 9.64 & 4.18 \\
\hline A7 & 1200 & 1473.15 & 13 & 686.63 & 1309.80 & $\mathrm{~S} 4$ & 450 & 723.15 & 150 & 9.64 & 3157.84 \\
\hline A8 & 497 & 770.15 & 1.01 & 739.87 & 491.04 & S5 & 325 & 598.15 & 20 & 9.64 & 3081.50 \\
\hline A9 & 272 & 544.94 & 1.01 & 739.87 & 249.32 & S6 & 470 & 743.15 & 20 & 9.64 & 3402.01 \\
\hline A10 & 266 & 539.15 & 1.01 & 739.87 & 243.07 & S7 & 190 & 463.15 & 1.7 & 9.64 & 2852.17 \\
\hline A11 & 75 & 348.15 & 1.01 & 739.87 & 45.71 & S8 & 31 & 304.15 & 1.7 & 86.97 & 4.18 \\
\hline Fuel & & & & & & S9 & 31 & 304.15 & 1.7 & 50.97 & 4.18 \\
\hline $\mathrm{F} 2$ & 163 & 436.15 & 13 & 71.43 & 219.96 & S11 & 31 & 304.15 & 1.7 & 36.00 & 4.18 \\
\hline Exhaust & & & & & & $\mathrm{S} 12$ & 127 & 400.15 & 1.7 & 36.00 & 2723.90 \\
\hline E1 & 1226 & 1499.15 & 11.8 & 124.30 & 1691.73 & $\mathrm{~S} 13$ & 190 & 463.15 & 1.7 & 36.00 & 2852.17 \\
\hline E2 & 761 & 1034.15 & 1.01 & 124.30 & 976.25 & $\mathrm{~S} 14$ & 190 & 463.15 & 1.7 & 86.97 & 2852.17 \\
\hline E3 & 680 & 953.15 & 1.01 & 124.30 & 849.85 & $\mathrm{~S} 15$ & 31 & 304.15 & 1.7 & 21.93 & 4.18 \\
\hline E4 & 640 & 913.15 & 1.01 & 124.30 & 788.41 & S16 & 190 & 463.15 & 1.7 & 21.93 & 2852.17 \\
\hline E5 & 517 & 790.15 & 1.01 & 124.30 & 604.96 & $\mathrm{~S} 17$ & 190 & 463.15 & 1.7 & 31.57 & 2852.17 \\
\hline E6 & 500 & 773.15 & 1.01 & 124.30 & 580.09 & $\mathrm{~S} 18$ & 39 & 312.15 & 0.069 & 118.54 & 2571.79 \\
\hline E7 & 128 & 401.15 & 1.01 & 124.30 & 76.98 & S19 & 30 & 303.15 & 1 & 118.54 & 0.00 \\
\hline E8 & 40 & 313.15 & 1.01 & 124.30 & 23.56 & $\mathrm{~S} 20$ & 30 & 303.15 & 1 & 108.90 & 0.00 \\
\hline E9 & 40 & 313.15 & 1.05 & 38.20 & 41.72 & & & & & & \\
\hline E10 & 40 & 313.15 & 1.05 & 86.09 & 8.54 & & & & & & \\
\hline E11 & 35 & 308.15 & 110 & 86.09 & 4.26 & & & & & & \\
\hline
\end{tabular}


Table 3: Energy analysis of combined cycle CLC based power plants operating in CCS and non CCS modes

\begin{tabular}{|c|c|c|c|c|}
\hline \multirow[b]{2}{*}{ Power produced/consumed } & \multicolumn{2}{|c|}{ Natural gas CC CLC } & \multicolumn{2}{|c|}{ Syngas CC CLC } \\
\hline & CCS Mode & $\begin{array}{l}\text { Non CCS } \\
\text { Mode }\end{array}$ & CCS Mode & $\begin{array}{l}\text { Non CCS } \\
\text { Mode }\end{array}$ \\
\hline \multicolumn{5}{|l|}{ Power produced } \\
\hline Air turbine $\left(\mathrm{kW}_{\mathrm{e}}\right)$ & 596,064 & 596,064 & 544,302 & 544,302 \\
\hline Carbon dioxide rich gas turbine $\left(\mathrm{kW}_{\mathrm{e}}\right)$ & 61,674 & 61,674 & 88,934 & 889,34 \\
\hline Steam turbine power $\left(\mathrm{kW}_{\mathrm{e}}\right)$ & 29,396 & 29,396 & 39,253 & 39,253 \\
\hline \multicolumn{5}{|l|}{ Power consumed } \\
\hline Air compression $\left(\mathrm{kW}_{\mathrm{e}}\right)$ & 275,716 & 275,716 & 251,197 & 251,197 \\
\hline $\mathrm{CO}_{2}$ compression to $110 \mathrm{bar}(\mathrm{kW})$ & 14,721 & - & 30,842 & - \\
\hline Water pump cost $\left(\mathrm{kW}_{\mathrm{e}}\right)$ & 10 & 10 & 202 & 202 \\
\hline Available power $\left(\mathrm{kW}_{\mathrm{e}}\right)$ & 396,6877 & 411,408 & 390,248 & 421,091 \\
\hline Thermal input $\left(\mathrm{kW}_{\mathrm{e}}\right)$ & 761,000 & 761,000 & 800,061 & 800,061 \\
\hline Net Efficiency (\%) & 52.13 & 54.06 & 48.78 & 52.63 \\
\hline
\end{tabular}


Table 4: Overall energy analysis for combined cycle CLC

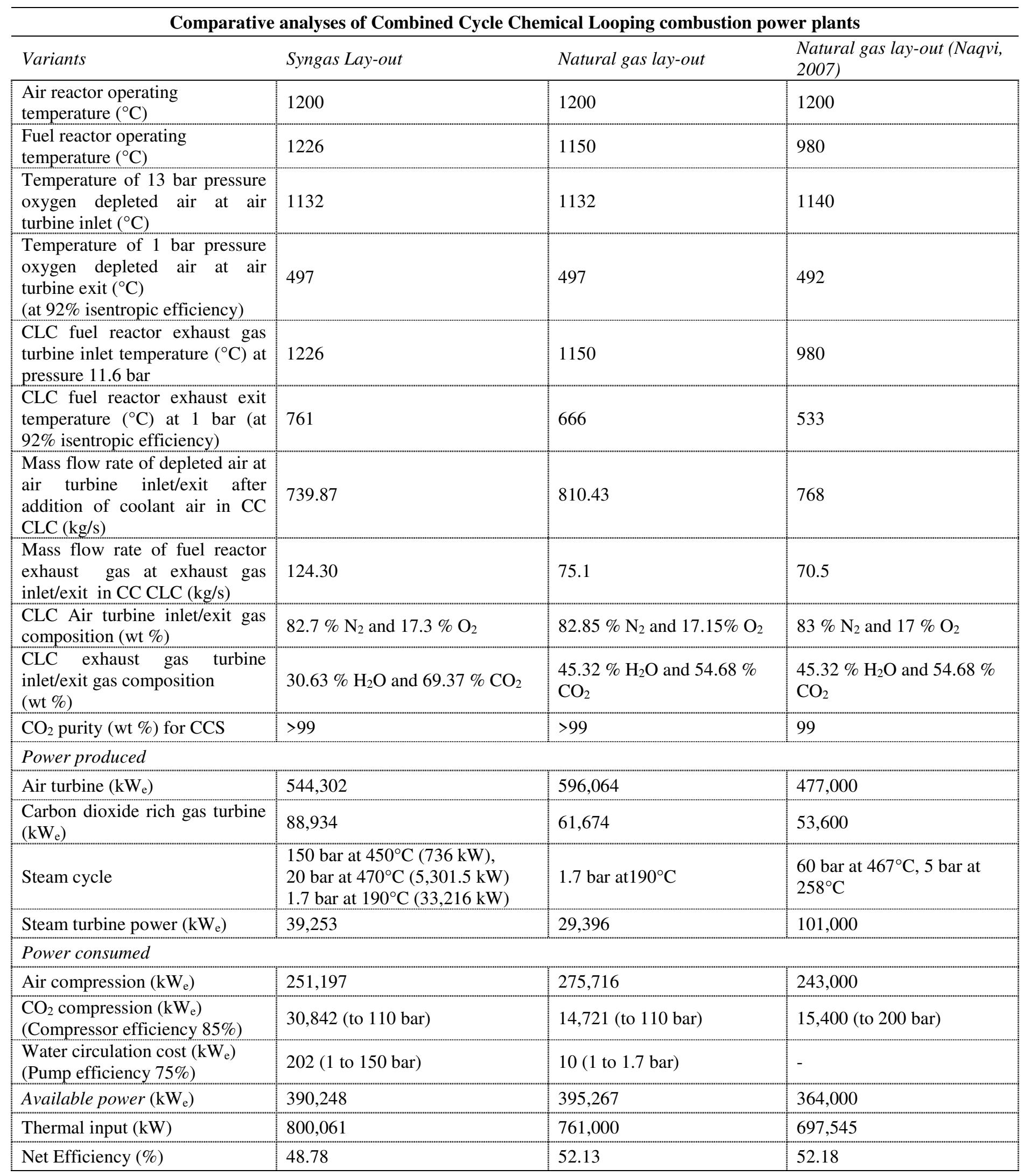

